\title{
RESEARCH
}

Open Access

\section{Palmitoylethanolamide counteracts substance P-induced mast cell activation in vitro by stimulating diacylglycerol lipase activity}

Stefania Petrosino ${ }^{1,2^{*}}$ (D), Aniello Schiano Moriello ${ }^{1,2}$, Roberta Verde $^{1}$, Marco Allarà ${ }^{1,2}$, Roberta Imperatore ${ }^{1}$, Alessia Ligresti ${ }^{1}$, Ali Mokhtar Mahmoud ${ }^{1}$, Alessio Filippo Peritore ${ }^{1}$, Fabio Arturo lannotti ${ }^{1}$ and Vincenzo Di Marzo ${ }^{1,3^{*}}$

\begin{abstract}
Background: Palmitoylethanolamide (PEA) is a pleiotropic endogenous lipid mediator currently used as a "dietary food for special medical purposes" against neuropathic pain and neuro-inflammatory conditions. Several mechanisms underlie PEA actions, among which the "entourage" effect, consisting of PEA potentiation of endocannabinoid signaling at either cannabinoid receptors or transient receptor potential vanilloid type-1 (TRPV1) channels. Here, we report novel molecular mechanisms through which PEA controls mast cell degranulation and substance P (SP)-induced histamine release in rat basophilic leukemia (RBL-2H3) cells, a mast cell model.

Methods: RBL-2H3 cells stimulated with SP were treated with PEA in the presence and absence of a cannabinoid type-2 (CB2) receptor antagonist (AM630), or a diacylglycerol lipase (DAGL) enzyme inhibitor (OMDM188) to inhibit the biosynthesis of the endocannabinoid 2-arachidonoylglycerol (2-AG). The release of histamine was measured by ELISA and $\beta$-hexosaminidase release and toluidine blue staining were used as indices of degranulation. 2-AG levels were measured by LC-MS. The mRNA expression of proposed PEA targets (Cnr1, Cnr2, Trpv1, Ppara and Gpr55), and of PEA and endocannabinoid biosynthetic (Napepld, Dagla and Daglb) and catabolic (Faah, Naaa and Mg) enzymes were also measured. The effects of PEA on the activity of DAGL- $\alpha$ or - $\beta$ enzymes were assessed in COS-7 cells overexpressing the human recombinant enzyme or in RBL-2H3 cells, respectively.

Results: SP increased the number of degranulated RBL-2H3 cells and triggered the release of histamine. PEA counteracted these effects in a manner antagonized by AM630. PEA concomitantly increased the levels of 2-AG in SP-stimulated RBL-2H3 cells, and this effect was reversed by OMDM188. PEA significantly stimulated DAGL-a and - $\beta$ activity and, consequently, 2-AG biosynthesis in cell-free systems. Co-treatment with PEA and 2-AG at per se ineffective concentrations downmodulated SP-induced release of histamine and degranulation, and this effect was reversed by OMDM188.

Conclusions: Activation of CB2 underlies the inhibitory effects on SP-induced RBL-2H3 cell degranulation by PEA alone. We demonstrate for the first time that the effects in RBL-2H3 cells of PEA are due to the stimulation of 2-AG biosynthesis by DAGLS.
\end{abstract}

Keywords: 2-arachidonoylglycerol, Diacylglycerol lipase, Mast cells, Neuroinflammation, Palmitoylethanolamide

\footnotetext{
* Correspondence: spetrosino@icb.cnr.it; vdimarzo@icb.cnr.it

$\wedge$ This article is dedicated to the memory of Stephen Skaper

'Endocannabinoid Research Group, Istituto di Chimica Biomolecolare,

Consiglio Nazionale delle Ricerche, Via Campi Flegrei 34, 80078 Pozzuoli

(Napoli), Italy

Full list of author information is available at the end of the article
}

(c) The Author(s). 2019 Open Access This article is distributed under the terms of the Creative Commons Attribution 4.0 International License (http://creativecommons.org/licenses/by/4.0/), which permits unrestricted use, distribution, and reproduction in any medium, provided you give appropriate credit to the original author(s) and the source, provide a link to the Creative Commons license, and indicate if changes were made. The Creative Commons Public Domain Dedication waiver (http://creativecommons.org/publicdomain/zero/1.0/) applies to the data made available in this article, unless otherwise stated. 


\section{Background}

Palmitoylethanolamide (PEA) was initially identified from the purified lipid fractions of egg yolk [1], and later found in a wide variety of food sources [2, 3]. In addition, PEA is also considered an endogenous lipid mediator produced on demand in several mammalian cell types and tissues to counteract inflammatory and other noxious responses [2]. Accordingly, PEA tissue concentrations are altered during several inflammatory disorders [2, 4]. For example, an increase of PEA levels was found both in human $\mathrm{HaCaT}$ keratinocytes stimulated with polyinosinic polycytidylic-acid (poly-(I:C)), an in vitro model of allergic contact dermatitis (ACD), and in the ear skin of 2,4-dinitrofluorobenzene (DNFB)-sensitized and challenged mice, an in vivo model of the early phase of ACD characterized by activation of keratinocytes [5]. Increased PEA levels were also found in the skin of dogs with atopic dermatitis [6]. On the other hand, decreased PEA levels were reported in granuloma in rats, a model of chronic inflammation sustained by neoangiogenesis [7], and in spinal and supraspinal brain regions involved in nociception in mice with neuropathic pain [8]. Therefore, while the increase of endogenous PEA levels in some disorders might be a compensatory response aiming at counteracting inflammatory processes, their decrease in other pathological conditions could contribute to the etiology of the disease.

In agreement with this hypothesis, exogenously administered PEA in the micrometer particle size range potentiates endogenous anti-inflammatory mechanisms in experimental models as well as in the clinic $[2,4,9,10]$. In granuloma, PEA reduced inflammatory hallmarks, including tumor necrosis factor (TNF)- $\alpha$ and granulomadependent angiogenesis [7]. Likewise, PEA inhibited the expression and release of the pro-inflammatory chemokine monocyte chemotactic protein-2 (MCP-2) in poly(I:C)-stimulated $\mathrm{HaCaT}$ cells in vitro, as well as DNFBinduced ear inflammation in mice during the early and late phase of ACD, the latter being characterized by activation of mast cells $(\mathrm{MC})[5,11]$. The anti-inflammatory effects of PEA in the early and late phase of ACD were blocked by antagonism at the transient receptor potential vanilloid type-1 (TRPV1) channels and cannabinoid receptor type-2 (CB2), respectively, despite the fact that the compound is inactive per se at both these targets $[12,13]$. Therefore, these effects were explained with the capability of PEA to elevate the levels or actions of endogenous agonists at cannabinoid receptors and TRPV1 receptors, i.e., anandamide (AEA) and oleoylethanolamide (OEA) [5, 14-16], and hence to exert an indirect receptor-mediated mechanism, known as the entourage effect $[13,17,18]$. Accordingly, PEA had been previously shown to increase either the endogenous levels [19], or the actions at TRPV1 channels [13, 18], of AEA, and, more recently, to enhance the endogenous levels of, and the activation/desensitization of TRPV1 by, 2arachidonoylglycerol (2-AG) [20], another endogenous lipid capable of activating both cannabinoid receptors and TRPV1 [21]. A stimulatory effect on 2-AG levels was recently suggested to occur also in the brain, following direct activation of $\mathrm{G}$ protein-coupled receptor 55 (GPR55) by PEA [22]. PEA was recently found to also elevate CB2 expression in microglia through direct activation of the peroxisome proliferator-activated nuclear receptor- $\alpha$ (PPAR $\alpha)$ [23], a well-established direct target of the lipid $[10,24]$. Indeed, the aforementioned stimulatory effect of PEA on AEA activation of TRPV1 was later shown to be due to the activation of PPAR $\alpha$ and subsequent sensitization by the latter of TRPV1 $[25,26]$. In summary, several direct or indirect receptor- and endocannabinoid/endovanilloid-mediated mechanisms, often in sequence or synergy with each other, have been proposed to explain the many CB2- and TRPV1-dependent effects of PEA [2].

Historically, the first, and possibly most important, anti-inflammatory effect of PEA to be ascribed to CB2 activation was the downregulation of MC degranulation, which was described in a widely used MC model, the rat basophilic leukemia (RBL-2H3) cells [27], when evidence for the lack of direct effect of the lipid on cannabinoid receptors was not yet available. Indeed, the negative control of $\mathrm{MC}$ activity is one of the most commonly suggested cellular mechanisms for the protective actions of PEA in vivo, among which the above mentioned inhibitory effects on granuloma and late phase $\operatorname{ACD}[7,11]$, and its counteraction of neurogenic inflammation (NI) and inflammatory and neuropathic pain [28-32]. Nevertheless, the exact mechanism through which PEA modulates MC degranulation is still unknown. Is this effect due to the upregulation of CB2 expression, as recently found in microglia [23]? Or is it due to elevation of the levels or activity of endocannabinoids, and in particular 2-AG, as shown in keratinocytes and brain neurons [20,22], given the much higher efficacy of this compound, compared to AEA, at CB2 receptors $[12,33]$ ?

In order to provide an answer to these questions, we investigated the mechanism(s) through which PEA counteracts substance $\mathrm{P}(\mathrm{SP})$-induced RBL-2H3 cell degranulation, and, in particular, the possibility that it does so by enhancing 2-AG levels. It is well known that 2-AG is mostly biosynthesized by two diacylglycerol lipases (DAGL)- $\alpha$ and - $\beta[4]$, and degraded to arachidonic acid and glycerol by monoacylglycerol lipase (MGL) [34]. Therefore, along with other possible molecular effects of PEA, we have assessed for the first time in different in vitro settings its possible stimulatory or 
inhibitory effects, respectively, on these enzymes, and the consequences of DAGL stimulatory effects on 2-AG biosynthesis by PEA in RBL-2H3 cells.

\section{Methods}

\section{Materials and reagents}

All reagents were purchased from Sigma-Aldrich (Milano, Italy) unless otherwise specified. RBL-2H3 cell line was purchased from LGC Standards (Milano, Italy). PEA in an ultra-micronized formulation was provided by the Epitech Group SpA (Saccolongo, Padova, Italy). PEA, when inserted in water after being dissolved in methanol, remained watersoluble up to $25 \mu \mathrm{M}$. AM630 and JWH133 were purchased from Tocris Bioscience (Space Import-Export, Milano, Italy). 2-AG was purchased from ENZO Life Sciences (Roma, Italy). OMDM188 was a kind gift from Dr. Giorgio Ortar (Sapienza Università di Roma, Roma, Italy). Deuterated standards- ${ }^{2}[\mathrm{H}]_{8}$-AEA, $\quad\left[{ }^{2} \mathrm{H}\right]_{5}-2$-AG and $\left[{ }^{2} \mathrm{H}\right]_{4}$-PEA-were purchased from Cayman Chemical (Cabru, Arcore, Italy). Histamine ELISA Kit was purchased from Abnova (Prodotti Gianni, Milano, Italy). Cyclic AMP assay was purchased from Eurofins-DiscoverX (Fremont, CA). MultiTox-Glo Multiplex Cytotoxicity kit was purchased from Promega Corporation (Promega Italia, Milano, Italy).

\section{Cell cultures}

RBL-2H3 cells were grown in Eagles Modified Essential Medium (EMEM) supplemented with glutamine (2 $\mathrm{mM})$, penicillin $(50 \mathrm{U} / \mathrm{ml})$, streptomycin $(50 \mu \mathrm{g} / \mathrm{ml})$ and $15 \%$ fetal bovine serum (FBS), in a humidified 5\% $\mathrm{CO}_{2}$ atmosphere at $37^{\circ} \mathrm{C}$, plated on $100 \mathrm{~mm}$ diameter Petri dishes.

\section{$\mathrm{SP}$-induced $\mathrm{NI}$ in RBL-2H3 cells}

RBL-2H3 cells were plated into 24-well culture dishes at a cell density of $2 \times 10^{5}$ cells per well, or into 6 -well culture dishes at a cell density of $9 \times 10^{5}$ cells per well, for 1 day at $37{ }^{\circ} \mathrm{C}$ in $5 \% \mathrm{CO}_{2}$ atmosphere. After 1 day, RBL$2 \mathrm{H} 3$ cells were stimulated with SP $(10 \mu \mathrm{M})$ or vehicle (water) and incubated for $15 \mathrm{~min}$ at $37{ }^{\circ} \mathrm{C}$ in $5 \% \mathrm{CO}_{2}$ atmosphere.

\section{$\beta$-Hexosaminidase release assay}

SP-stimulated RBL-2H3 cells $\left(2 \times 10^{5}\right.$ cells/well $)$ were treated with PEA $(0.1,0.5,1$, and $10 \mu \mathrm{M})$ or vehicle (methanol, max $0.1 \%$ ) for $15 \mathrm{~min}$ at $37^{\circ} \mathrm{C}$ in $5 \% \mathrm{CO}_{2}$ atmosphere. After $15 \mathrm{~min}$, the supernatants $(15 \mu \mathrm{l})$ were transferred to 96-well plates and incubated with $60 \mu \mathrm{l}$ of substrate $(1 \mathrm{mM} p$-nitrophenyl- $N$-acetyl- $\beta$-D-glucosaminide in citrate $0.05 \mathrm{M}, \mathrm{pH} 4.5$ ) for $1 \mathrm{~h}$ at $37{ }^{\circ} \mathrm{C}$. To determine the total amount of released $\beta$-hexosaminidase, the cells were lysed with $0.1 \%$ Triton X-100 and incubated with substrate using the same procedure as for the determination of the activity in the supernatants. The reaction was stopped by adding $150 \mu \mathrm{l}$ of $0.1 \mathrm{M}$ sodium bicarbonate buffer ( $\mathrm{pH}$ 10.0), and the reaction product was monitored by measuring the optical density (OD) at $405 \mathrm{~nm}$ by using a reader GENios Pro (Tecan). The results were expressed as $\%$ of the total $\beta$-hexosaminidase content of the cells determined by cell lysis with $0.1 \%$ Triton X-100, and calculated by using the following formula: \% degranulation $=\left[\mathrm{OD}_{\text {supernatant }} /\left(\mathrm{OD}_{\text {supernatant }}+\right.\right.$ $\left.\left.\mathrm{OD}_{\text {triton } x-100}\right)\right] \times 100$.

\section{Histamine release assay}

SP-stimulated RBL-2H3 cells $\left(2 \times 10^{5}\right.$ cells/well $)$ were treated with PEA $(10 \mu \mathrm{M})$ or vehicle (methanol) for 15 min at $37{ }^{\circ} \mathrm{C}$ in $5 \% \mathrm{CO}_{2}$ atmosphere. SP-stimulated RBL-2H3 cells were also treated with a CB2 antagonist, AM630 $(0.1 \mu \mathrm{M})$, in the presence and absence of PEA $(10 \mu \mathrm{M})$, or JWH133 $(0.1 \mu \mathrm{M})$ (a CB2 synthetic agonist), and incubated for the indicated time. SP-stimulated RBL-2H3 cells were also treated with 2-AG (0.1 and 1 $\mu \mathrm{M})$, or co-treated with PEA $(0.1 \mu \mathrm{M})$ and 2-AG $(0.1$ $\mu \mathrm{M})$, and incubated for the indicated time. SPstimulated RBL-2H3 cells were also co-treated with PEA $(10 \mu \mathrm{M})$ and OMDM188 $(10 \mu \mathrm{M})$ (a DAGL inhibitor), and incubated for the indicated time. After $15 \mathrm{~min}$, the supernatants were collected and the amounts of secreted histamine were measured by using a histamine ELISA kit according to the manufacturer's instructions (Abnova) and by using a reader GENios Pro (Tecan). Data were expressed as nanograms per milliliter of histamine.

\section{MultiTox-Glo multiplex cytotoxicity assay}

The relative number of live and dead cells was measured after 15 min in RBL-2H3 cells $\left(2 \times 10^{5}\right.$ cells/well $)$ stimulated with SP $(10 \mu \mathrm{M})$ and treated with PEA $(10 \mu \mathrm{M})$ by using MultiTox-Glo multiplex cytotoxicity kit, according to the manufacturer's instructions (Promega Italia). Relative fluorescence units (RFU) were measured by using a GloMax Multi Detection System (Promega Italia).

\section{Toluidine blue staining}

SP-stimulated RBL-2H3 cells [plated on poly-L-lysine $(33 \mu \mathrm{g} / \mathrm{ml})$ coated slides (Deckglaser, $21 \times 26 \mathrm{~mm})$ into 6-well culture dishes at a cell density of $9 \times 10^{5}$ cells per well] were treated and incubated as described above for histamine release assay. After $15 \mathrm{~min}$, the cells were fixed with paraformaldehyde at $4 \%$ for $20 \mathrm{~min}$ and incubated for 3 min with toluidine blue at $0.01 \%$ in $3 \%$ acetic acid. Subsequently, a $5 \mathrm{~min}$ wash in distilled water and dehydration in increasing alcohols $(90 \%, 100 \%)$ were performed. Cells were then clarified by treatment with Xylol for $5 \mathrm{~min}$ and finally dried slides were mounted with the DPX histogram upright. The cells were observed using a Leica DMI6000 digital microscope, 
acquired using the Leica DFC 340FX digital camera connected to the microscope and analyzed using the LAS AF 2.2.0 software. Degranulated RBL-2H3 cells were counted and the percentage of degranulation (based on the number of colorable cells) was calculated.

\section{Measurement by LC-APCI-MS of endogenous AEA, 2-AG, and PEA levels}

RBL-2H3 cells $\left(9 \times 10^{5}\right.$ cells/well $)$ were stimulated with SP $(10 \mu \mathrm{M})$ and treated with PEA $(10 \mu \mathrm{M})$ in the presence and absence of OMDM188 $(10 \mu \mathrm{M})$, for $15 \mathrm{~min}$ at $37{ }^{\circ} \mathrm{C}$ in $5 \% \mathrm{CO}_{2}$ atmosphere. After $15 \mathrm{~min}$, cells and supernatants were collected and homogenized in a solution of $\mathrm{CHCl}_{3} / \mathrm{CH}_{3} \mathrm{OH} /$ Tris- $\mathrm{HCl} 50 \mathrm{mM}$ pH 7.4 (2:1:1, v/v) containing 10 pmol of $\left[{ }^{2} \mathrm{H}\right]_{8}$-AEA, $\left[{ }^{2} \mathrm{H}\right]_{5}$-2-AG and $\left[{ }^{2} \mathrm{H}\right]_{4}$-PEA as internal standards [35]. The lipid-containing organic phase was dried down, weighed and pre-purified by openbed chromatography on silica gel. Fractions obtained by eluting the column with a solution of $\mathrm{CHCl}_{3} / \mathrm{CH}_{3} \mathrm{OH}$ (90: 10 by vol.) were analyzed by Liquid ChromatographyAtmospheric Pressure Chemical Ionization-Mass Spectrometry (LC-APCI-MS) using a Shimadzu (Shimadzu, Kyoto, Japan) HPLC apparatus (LC-10ADVP) coupled to a Shimadzu (LCMS-2020) quadrupole MS via a Shimadzu APCI interface. LC-APCI-MS analyses of 2-AG and PEA were carried out in the selected ion monitoring mode [19, 36], using $m / z$ values of 356 and 348 (molecular ions +1 for deuterated and undeuterated AEA), 384.35 and 379.35 (molecular ions +1 for deuterated and undeuterated 2AG), and 304 and 300 (molecular ions +1 for deuterated and undeuterated PEA). AEA, 2-AG and PEA levels were calculated on the basis of their area ratio with the internal deuterated standard signal areas, and their amounts (pmol) were normalized per mg of lipid extract.

\section{Quantitative real-time PCR}

The mRNA expression of PEA target genes ( $\mathrm{Cnr} 1, \mathrm{Cnr} 2$, Trpv1, Ppara, and Gpr55), as well as PEA and 2-AG biosynthetic (N-acyl phosphatidylethanolamine-specific phospholipase D, Napepld, Dagla and Daglb) and catabolic enzyme genes (fatty acid amide hydrolase, Faah; $N$ acylethanolamine-hydrolyzing acid amidase, Naaa; and monoacylglycerol lipase, $M g l$ ), was studied by comparison of transcriptional expression in unstimulated RBL-2H3 cells (plated on $100 \mathrm{~mm}$ diameter Petri dishes) vs. the expression of these targets and enzymes in RBL-2H3 cells treated with PEA $(10 \mu \mathrm{M})$, or stimulated with SP $(10 \mu \mathrm{M})$ in the presence and absence of PEA $(10 \mu \mathrm{M})$, for $15 \mathrm{~min}$ at $37{ }^{\circ} \mathrm{C}$ in $5 \% \mathrm{CO}_{2}$ atmosphere. Total RNA was purified, quantified and reverse transcribed as previously reported [37]. For each target, all mRNA sequences were aligned and common primers were designed (Table 1). Quantitative real-time PCR was performed by an iCycler-iQ5 in a $20 \mu \mathrm{l}$ reaction mixture using $20 \mathrm{ng}$ of cDNA. Assays were
Table 1 List of primer sequences used in qPCR analysis

\begin{tabular}{|c|c|c|}
\hline Gene & Forward sequences $\left(5^{\prime}->3^{\prime}\right)$ & Reverse sequences $\left(5^{\prime}->3^{\prime}\right)$ \\
\hline Cnrl & CTGAGGGTTCCCTCCCGGCA & TGCTGGGACCAACGGGGAGT \\
\hline Cnr2 & GCAACTTCGTCATCTTCC & AGCACAGACATAGGTATCG \\
\hline Trpv1 & CATCTTCACTACCAGGAG & TGGATAGTTAGAACAGAGC \\
\hline Ppara & CCTCAGGATACCACTATG & TGTTCACAGGTAAGGATT \\
\hline Gpr55 & TCTTCTGGTCAATCACTT & AATGCTCAGTAGAATGTG \\
\hline Napepld & CGCCAAGCCATCAGTATCC & ATCCTTCTCCATTATCAGCCATC \\
\hline Dagla & ATGATGGTGCCTGAGAGC & AGTGGGAAGGAGGGTGAG \\
\hline Daglb & AAGGTATCCAATGTGACAGG & CAGCGATGACAATCCAACT \\
\hline Faah & ACTGCGTGACCTCCTATC & CACAGTCAGATTCCGATGG \\
\hline Naaa & CACTITTGTTGGCTATGTAG & TCTCGTTCATCACCAGAA \\
\hline$M g l$ & GTCCTTGCTGCCAAACTG & TCCGACTTGTTCCGAGAC \\
\hline$\beta$-actin & CCAGGCATTGCTGACAGG & TGGAAGGTGGACAGTGAGG \\
\hline HPRT & TTGACACTGGTAAAACAATGC & GCCTGTATCCAACACTTCG \\
\hline
\end{tabular}

performed in quadruplicate (maximum $\Delta \mathrm{Ct}$ of replicate samples < 0.5). Optimized primers for SYBR-green analysis and optimum annealing temperatures were designed by the Allele-Id software version 7.0 (Biosoft International) and were synthesized (HPLC-purification grade) by MWG-Biotech. Relative expression calculation was corrected for PCR efficiency, normalized with respect to the reference genes $\beta$-actin and hypoxanthine phosphoribosyltransferase (HPRT) and performed by the iQ5 software. Results were expressed as fold expression compared with a reference condition $\left(2^{\wedge}-\Delta \Delta\right.$ ct formula).

\section{Competition binding assay for $\mathrm{CB} 2$ receptors}

Membranes from Human Embryonic Kidney (HEK)-293 cells overexpressing the human recombinant CB2 receptor $\left(B_{\max }=4.7 \mathrm{pmol} / \mathrm{mg}\right.$ protein $)$ were incubated with $\left[{ }^{3} \mathrm{H}\right]-\mathrm{CP}-55,940\left(0.084 \mathrm{nM} / \mathrm{k}_{\mathrm{d}}=0.31 \mathrm{nM}\right)$ as the highaffinity ligand. Competition curves were performed by displacing $\left[{ }^{3} \mathrm{H}\right]-\mathrm{CP}-55,940$ with increasing concentration of PEA $(0.01-10 \mu \mathrm{M})$, or 2-AG $(0.001-100 \mu \mathrm{M})$ both in the absence and presence of PEA $(1,5$, and $10 \mu \mathrm{M})$, for $90 \mathrm{~min}$ at $30{ }^{\circ} \mathrm{C}$, following the procedure described by the manufacturer (Perkin Elmer, Monza, Italy), and as previously reported [38]. Non-specific binding was defined by $10 \mu \mathrm{M}$ of WIN55,212-2 (Tocris Bioscience) as the heterologous competitor $\left(K_{i}=2.1 \mathrm{nM}\right)$. Data were expressed as $K_{i}(\mu \mathrm{M})$ and calculated by applying the Cheng-Prusoff equation to the $\mathrm{IC}_{50}$ values for the displacement of the bound radioligand.

\section{Functional activity assay at the CB2 receptors}

The cAMP Hunter ${ }^{\mathrm{Tm}}$ eXpress $\mathrm{G}$ protein-coupled receptor (GPCR) assay was performed in Chinese Hamster Ovary ( $\mathrm{CHO})-\mathrm{Kl}$ cells overexpressing the human $\mathrm{CB} 2$ receptor. $\mathrm{G}_{\mathrm{i}}$-coupled cAMP modulation was measured following 
the manufacturer's protocol (DiscoverX, Fremont, CA). CHO-K1 cells overexpressing the human CB2 receptor were plated into a 96-well plate $\left(3 \times 10^{4}\right.$ cells/well) and incubated overnight at $37{ }^{\circ} \mathrm{C}$ in $5 \% \mathrm{CO}_{2}$ atmosphere. The media were aspirated and replaced with $30 \mu \mathrm{l}$ of assay buffer. Cells were incubated $30 \mathrm{~min}$ at $37^{\circ} \mathrm{C}$ with $15 \mu \mathrm{l}$ of $3 \times$ concentration-response solutions of 2-AG $(0.01-50 \mu \mathrm{M})$, or PEA $(10 \mu \mathrm{M})$, prepared in presence of cell assay buffer containing a $3 \times$ of $25 \mu \mathrm{M} \mathrm{NKH-477} \mathrm{so-}$ lution (a water-soluble analog of Forskolin) to stimulate adenylate cyclase and enhance basal cAMP levels. We also investigated the effect of PEA on 2-AG receptor activation by co-incubation. Therefore, cells were also incubated 30 min at $37^{\circ} \mathrm{C}$ with 2-AG and PEA $(10 \mu \mathrm{M})$ in the presence of $\mathrm{NKH}-477$ to stimulate adenylate cyclase and enhance cAMP levels. Following stimulation, cell lysis, and cAMP detection were performed according to the manufacturer protocol (Promega Italia) [39]. Relative luminescence units (RLU) were measured by using a GloMax Multi Detection System (Promega Italia). Data were normalized considering the NKH-477 stimulus alone as $100 \%$ of the response. The percentage of response was calculated by using the following formula: \% RESPONSE $=100 \% \times(1-(\mathrm{RLU}$ of test compound-RLU of NKH-477 positive control)/(RLU of vehicle-RLU of NKH-477 positive control).

\section{DAGL-a enzyme activity assay}

DAGL- $\alpha$ enzyme activity was assessed as previously reported $[40,41]$ by using membrane preparations $(50 \mu \mathrm{g}$ of protein) obtained from COS-7 cells overexpressing the human recombinant DAGL- $\alpha$ enzyme, and 1$\left[{ }^{14} \mathrm{C}\right]$ oleoyl-2-arachidonoylglycerol $(1.0 \mathrm{mCi} / \mathrm{mmol}, 25$ $\mu \mathrm{M}$, synthesized as previously reported [40,41], as substrate in the presence of vehicle or increasing concentrations of PEA $(0.1-25 \mu \mathrm{M})$ in Tris- $\mathrm{HCl} 50 \mathrm{mM}$ pH 7.4. After the incubation $\left(20 \mathrm{~min}\right.$ at $\left.37^{\circ} \mathrm{C}\right)$, lipids were extracted with two volumes of $\mathrm{CHCl}_{3} / \mathrm{CH}_{3} \mathrm{OH}(2: 1, \mathrm{v} / \mathrm{v})$. The organic extracts, lyophilized under vacuum, were used to quantify the levels of 2-AG by LC-APCI-MS (as described above), or purified by using TLC on silica on polypropylene plates eluted in $\mathrm{CHCl}_{3} / \mathrm{CH}_{3} \mathrm{OH} / \mathrm{NH}_{4} \mathrm{OH}$ $(85: 15: 0.1 \%, \mathrm{v} / \mathrm{v})$ as the eluting solvent. Bands corresponding to $\left[{ }^{14} \mathrm{C}\right]$-oleic acid were cut and their radioactivity was measured by using Liquid Scintillation Analyzer (TRI-carb 2100TR). Data were expressed as \% of DAGL- $\alpha$ stimulation. To quantify the levels of 2-AG by LC-APCI-MS a non-radiolabeled 1-oleoyl-2-arachidonoylglycerol substrate was used.

\section{DAGL- $\beta$ enzyme activity assay}

DAGL- $\beta$ enzyme activity was assessed by using membrane preparations $(100 \mu \mathrm{g}$ of protein) obtained from RBL-2H3 cells, and 1- $\left[{ }^{14} \mathrm{C}\right]$ oleoyl-2-arachidonoylglycerol
$(1.0 \mathrm{mCi} / \mathrm{mmol}, 50 \mu \mathrm{M},[40,41])$, as substrate in the presence of vehicle or increasing concentrations of PEA $(1-25 \mu \mathrm{M})$ in Tris- $\mathrm{HCl} 50 \mathrm{mM} \mathrm{pH} 7.4$ or in Tris- $\mathrm{HCl}$ $50 \mathrm{mM} \mathrm{pH} 7.4$ and $\mathrm{CaCl}_{2} 10 \mathrm{mM}$. After the incubation $\left(20 \mathrm{~min}\right.$ at $37^{\circ} \mathrm{C}$ ), the protocol followed the same procedures as above reported for DAGL- $\alpha$ enzyme activity assay. Data were expressed as \% of activity of DAGL- $\beta$.

\section{MGL enzyme activity assay}

The 10,000 ×g cytosolic fractions obtained from COS-7 cells (100 $\mu \mathrm{g}$ of protein) were incubated with 2arachidonoyl- $\left[{ }^{3} \mathrm{H}\right]$-glycerol $(40 \mathrm{Ci} / \mathrm{mmol}$, St. Louis, MO, USA) diluted with non-radiolabeled 2-AG $(20 \mu \mathrm{M})$ in the presence of vehicle or increasing concentrations of PEA (0.1-25 $\mu \mathrm{M})$, in Tris- $\mathrm{HCl} 50 \mathrm{mM} \mathrm{pH} 7.4$ at $37{ }^{\circ} \mathrm{C}$ for $20 \mathrm{~min}$ [42]. After the incubation, the amounts of $\left[{ }^{3} \mathrm{H}\right]$-glycerol were measured in the aqueous phase [after extraction of the incubation mixture with 2 volumes of $\left.\mathrm{CHCl}_{3} / \mathrm{CH}_{3} \mathrm{OH}(1: 1, \mathrm{v} / \mathrm{v})\right]$ by using Liquid Scintillation Analyzer (TRI-carb 2100TR).

\section{Statistical analysis}

Each experiment was performed at least three times with triplicate groups. Data were expressed as means \pm standard error of the mean (SEM). Statistical analyses were performed using GraphPad Prism software version 7.0 (GraphPad Software Inc., San Diego, CA). One-way analysis of variance (ANOVA) followed by Newman-Keuls multiple comparison test was used for analysis. $p$ values $<0.05$ were considered statistically significant. Figures were generated in GraphPad Prism software version 7.0.

\section{Results}

PEA reduces $\beta$-hexosaminidase and histamine release from SP-stimulated RBL-2H3 cells

RBL-2H3 cells stimulated with SP $(10 \mu \mathrm{M}$ for $15 \mathrm{~min})$ and treated with the vehicle of PEA significantly released $\beta$-hexosaminidase and histamine, as compared to vehicle-stimulated RBL-2H3 cells (Fig. 1a, b). PEA (0.1, $0.5,1$, and $10 \mu \mathrm{M})$, in a concentration-dependent manner, strongly reduced the release of $\beta$-hexosaminidase from SP-stimulated RBL-2H3 cells, as compared to SPstimulated RBL-2H3 cells treated with the vehicle of PEA (Fig. 1a). The maximum effect was observed at the highest concentration tested of PEA $(10 \mu \mathrm{M})$ (Fig. 1a), which also inhibited the release of histamine from SPstimulated RBL-2H3 cells, as compared to SP-stimulated RBL-2H3 cells treated with the vehicle of PEA (Fig. 1b). No effect on $\beta$-hexosaminidase and histamine release was observed if RBL-2H3 cells were treated with PEA alone $(10 \mu \mathrm{M})$, i.e., in the absence of SP, as compared to vehicle-treated RBL-2H3 cells (data not shown). 


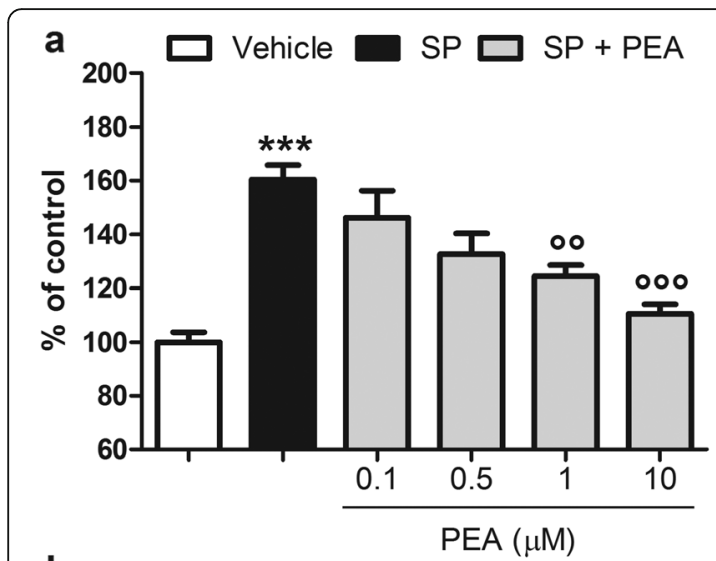

b

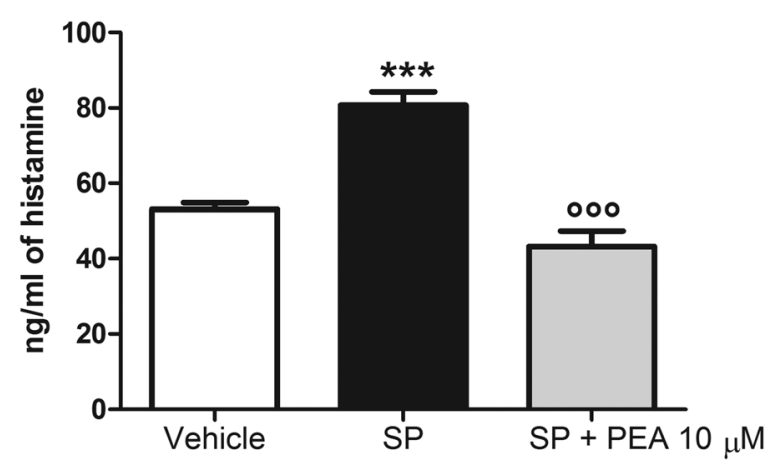

Fig. 1 PEA reduces $\beta$-hexosaminidase and histamine release from SP-stimulated RBL-2H3 cells. a $\beta$-hexosaminidase release was measured after stimulation of RBL-2H3 cells with SP $(10 \mu \mathrm{M})$ in the presence or absence of PEA $(0.1,0.5,1$, and $10 \mu \mathrm{M})$ for $15 \mathrm{~min}$ at 37 ${ }^{\circ} \mathrm{C}$ in a $5 \% \mathrm{CO}_{2}$ atmosphere. Absorbance was measured at $405 \mathrm{~nm}$. Each bar shows the mean \pm SEM. ${ }^{* * *} p<0.001$ compared with Vehicle. ${ }^{\circ 0} p<0.01$ and ${ }^{000} p<0.001$ compared with SP. b Histamine release by ELISA was performed after stimulation of RBL-2H3 cells with SP $(10 \mu \mathrm{M})$ in the presence or absence of PEA $(10 \mu \mathrm{M})$, for the indicated time. Absorbance was measured at $450 \mathrm{~nm}$. Each bar shows the mean \pm SEM. ${ }^{* * *} p<0.001$ compared with vehicle. ${ }^{000} p<$ 0.001 compared with SP

PEA does not affect the viability and cytotoxicity of both unstimulated and SP-stimulated RBL-2H3 cells

No effect on viability and cytotoxicity was observed after stimulation of RBL-2H3 cells with SP (10 $\mu \mathrm{M}$ for $15 \mathrm{~min})$ and the vehicle of PEA, as compared to vehicle-stimulated RBL-2H3 cells (Fig. 2a, b). Likewise, PEA $(10 \mu \mathrm{M})$ did not alter the viability and cytotoxicity of SP-stimulated RBL$2 \mathrm{H} 3$ cells, as compared to vehicle-stimulated RBL-2H3 cells (Fig. 2a, b). No effect on viability and cytotoxicity was also observed when RBL-2H3 cells were treated with PEA alone $(10 \mu \mathrm{M})$, i.e., in the absence of SP, as compared to vehicle-treated RBL-2H3 cells (Fig. 2a, b).

A CB2 receptor antagonist blocks the effect of PEA on histamine release from SP-stimulated RBL-2H3 cells When RBL-2H3 cells were stimulated with SP $(10 \mu \mathrm{M}$ for $15 \mathrm{~min}$ ) and treated with a selective (AM630) CB2 receptor antagonist (at the concentration of $0.1 \mu \mathrm{M}$ ), histamine release was comparable to that observed in SP-stimulated RBL-2H3 cells treated with the vehicle (Fig. 3a). Interestingly, when SP-stimulated RBL-2H3 cells were co-treated with PEA $(10 \mu \mathrm{M})$ and AM630 (0.1 $\mu \mathrm{M})$, histamine release was comparable to that observed in SP-stimulated RBL-2H3 cells treated with the vehicle, or with AM630 $(0.1 \mu \mathrm{M})$ (Fig. 3a). No effect was observed on histamine release when RBL-2H3 cells were treated with the antagonist alone (data not shown).

\section{A synthetic CB2 agonist inhibits histamine release from SP-stimulated RBL-2H3 cells}

JWH133 $(0.1 \mu \mathrm{M})$, a synthetic CB2 receptor agonist, inhibited the release of histamine from SP-stimulated RBL-2H3 cells, as compared to SP-stimulated RBL-2H3 cells treated with the vehicle (Fig. 3b). When SPstimulated RBL-2H3 cells were co-treated with JWH133 $(0.1 \mu \mathrm{M})$ and AM630 $(0.1 \mu \mathrm{M})$, histamine release was comparable to that observed in SP-stimulated RBL-2H3 cells treated with the vehicle (Fig. 3b). No effect was observed on histamine release when RBL-2H3 cells were treated with JWH133 alone $(0.1 \mu \mathrm{M})$, i.e., in the absence of SP (data not shown).

PEA and JWH133 downmodulate SP-induced degranulation of RBL-2H3 cells via a CB2-mediated mechanism

SP (10 $\mu \mathrm{M}$ for $15 \mathrm{~min}$ ) increased the number of degranulated RBL-2H3 cells, as compared to vehiclestimulated cells (Fig. 4a, c). PEA $(10 \mu \mathrm{M})$ reduced the number of SP-degranulated RBL-2H3 cells, as compared to SP-stimulated RBL-2H3 cells treated with the vehicle (Fig. 4a, c). When SP-stimulated RBL-2H3 cells were treated with AM630 $(0.1 \mu \mathrm{M})$, the number of degranulated RBL-2H3 cells was comparable to that measured in SP-stimulated RBL-2H3 cells treated with the vehicle, i.e., in the absence of the antagonist (Fig. $4 \mathrm{a}-\mathrm{c})$. More importantly, when SP-stimulated RBL-2H3 cells were co-treated with PEA $(10 \mu \mathrm{M})$ and AM630 $(0.1 \mu \mathrm{M})$, the number of degranulated RBL-2H3 cells was again comparable to that measured in SPstimulated RBL-2H3 cells treated with the vehicle, i.e., in the absence of both PEA and the antagonist (Fig. 4ac), or with the antagonist, i.e., in the absence of PEA (Fig. 4b, c). In addition, we observed that JWH133 (0.1 $\mu \mathrm{M})$, similar to PEA $(10 \mu \mathrm{M})$, also reduced the number of SP-degranulated RBL-2H3 cells, as compared to SPstimulated RBL-2H3 cells treated with the vehicle (Fig. $4 \mathrm{a}, \mathrm{c})$, and its effect was reversed by AM630 (0.1 $\mu \mathrm{M})$ (Fig. $4 \mathrm{a}-\mathrm{c}$ ). In fact, the number of SP-degranulated RBL-2H3 cells following co-treatment with JWH133 $(0.1 \mu \mathrm{M})$ and AM630 $(0.1 \mu \mathrm{M})$ was comparable to that measured in SP-stimulated RBL-2H3 cells treated only 


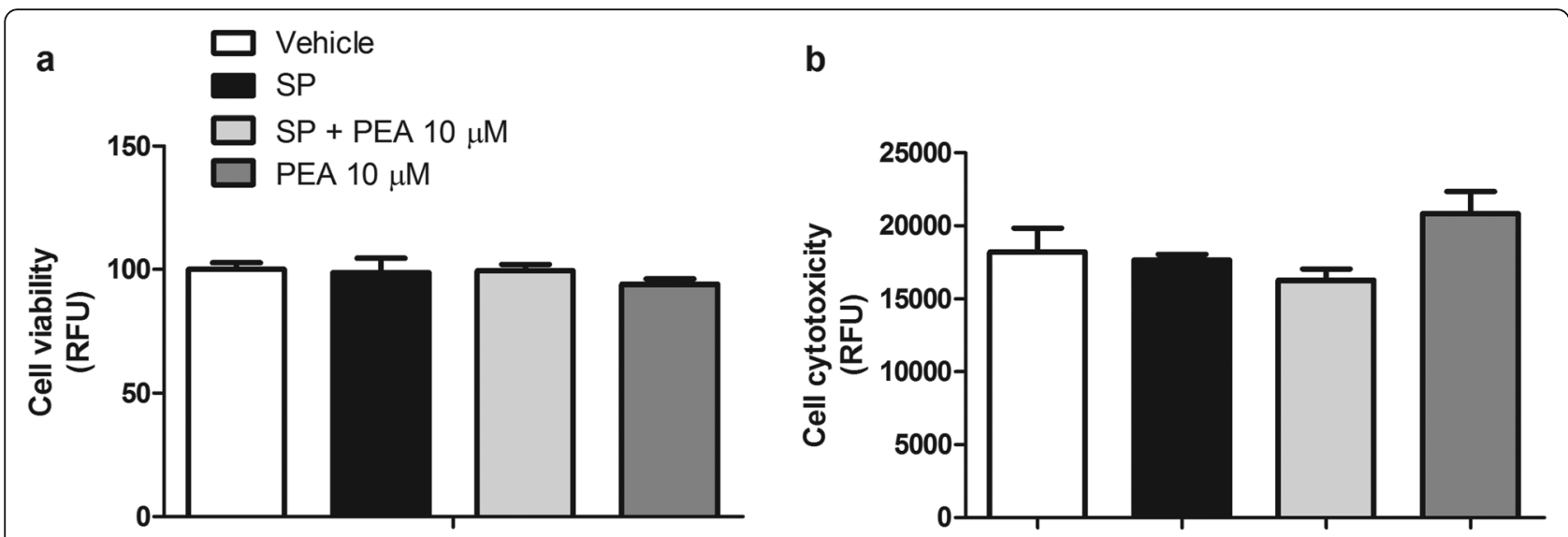

Fig. 2 Effect of PEA on cell viability and cytotoxicity of both unstimulated and SP-stimulated RBL-2H3 cells. a, b Cell viability and cytotoxicity were assessed, by means of a MultiTox-Glo assay after that RBL-2H3 cells were treated with PEA $(10 \mu \mathrm{M})$ or stimulated with SP $(10 \mu \mathrm{M})$ in the presence or absence of PEA $(10 \mu \mathrm{M})$ for $15 \mathrm{~min}$ at $37{ }^{\circ} \mathrm{C}$ in a $5 \% \mathrm{CO}_{2}$ atmosphere. RFU was measured at $495 \mathrm{~nm}$ and $505 \mathrm{~nm}$ (a). RFU was measured at $500 \mathrm{~nm}$ and $550 \mathrm{~nm}$ (b). Each bar shows the mean \pm SEM

with the vehicle (Fig. $4 \mathrm{a}-\mathrm{c}$ ), or only with the antagonist (Fig. 4b, c). Finally, no effect was observed on degranulation when RBL-2H3 cells were treated with PEA (10 $\mu \mathrm{M})$ or JWH133 $(0.1 \mu \mathrm{M})$ alone, i.e., in the absence of SP (data not shown).

PEA increases the levels of 2-AG in both unstimulated and SP-stimulated RBL-2H3 cells

When RBL-2H3 cells were stimulated with SP under the same conditions shown above to induce preformed mediator release and degranulation $(10 \mu \mathrm{M}$ for $15 \mathrm{~min})$, the endogenous levels of AEA, 2-AG, and PEA did not change, as compared to RBL-2H3 cells stimulated with vehicle (Fig. $5 \mathrm{a}-\mathrm{c})$. By contrast, when SP-stimulated RBL-2H3 cells were treated with PEA $(10 \mu \mathrm{M})$, the endogenous levels of 2-AG were significantly increased by 1.4-fold compared to RBL$2 \mathrm{H} 3$ cells only treated with vehicle (Fig. $5 \mathrm{~b}$ ), and by 1.6 -fold compared to SP-stimulated RBL-2H3 cells treated with the PEA vehicle (Fig. 5b). In addition, the endogenous levels of 2-AG were also significantly increased by 1.8 -fold when RBL-2H3 cells were treated with PEA $(10 \mu \mathrm{M})$ alone, i.e., in the absence of SP, as compared to vehicle-treated RBL-2H3

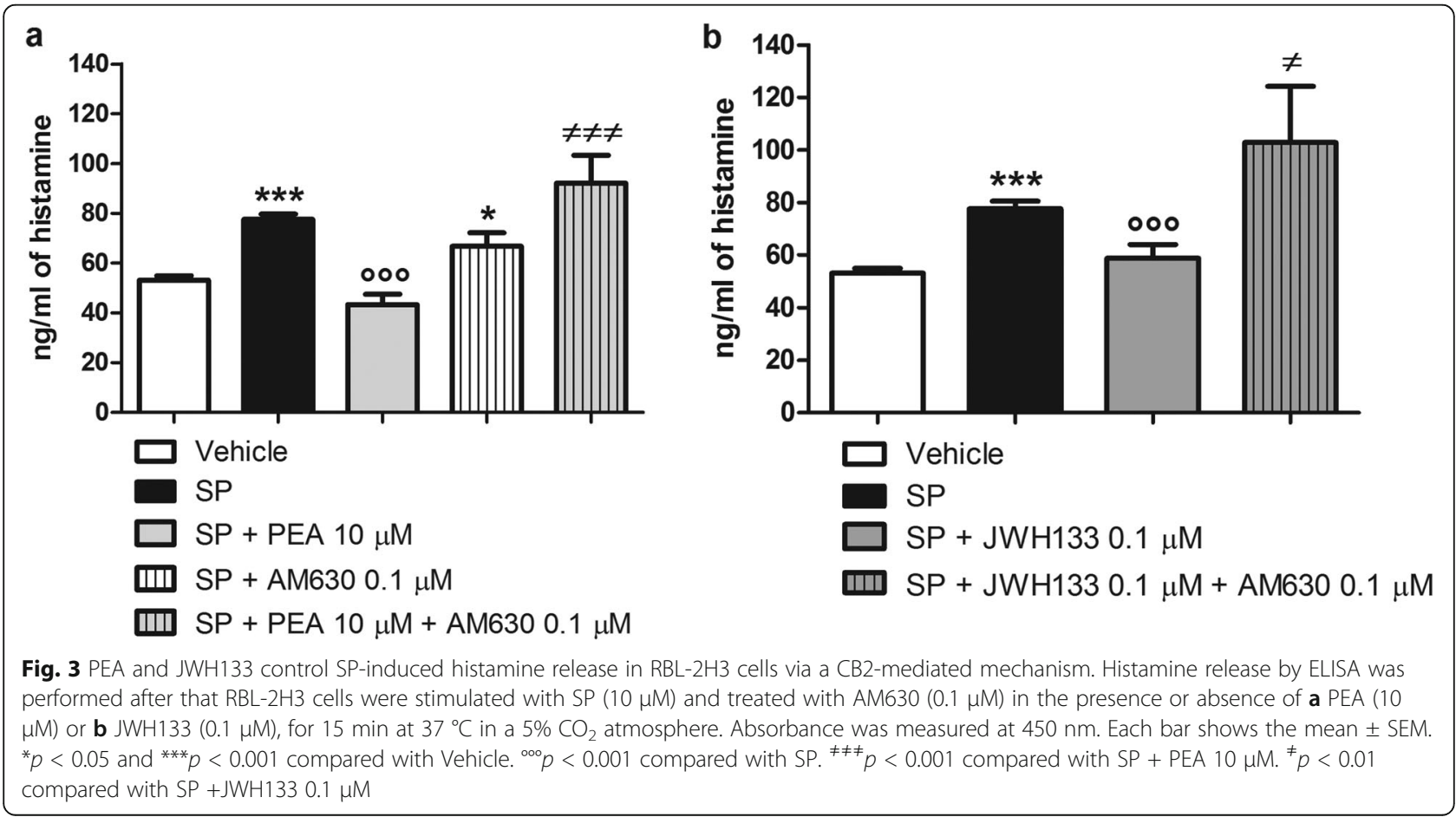




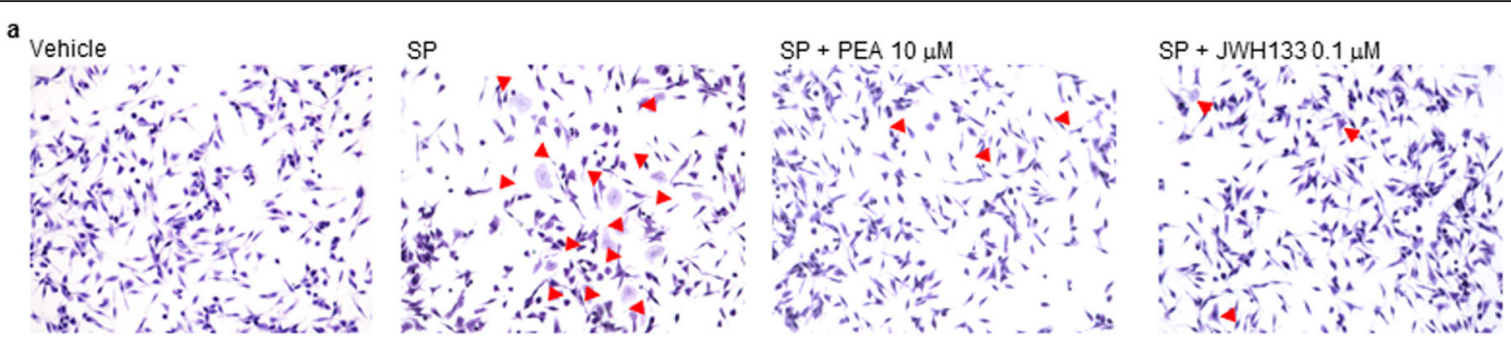

b
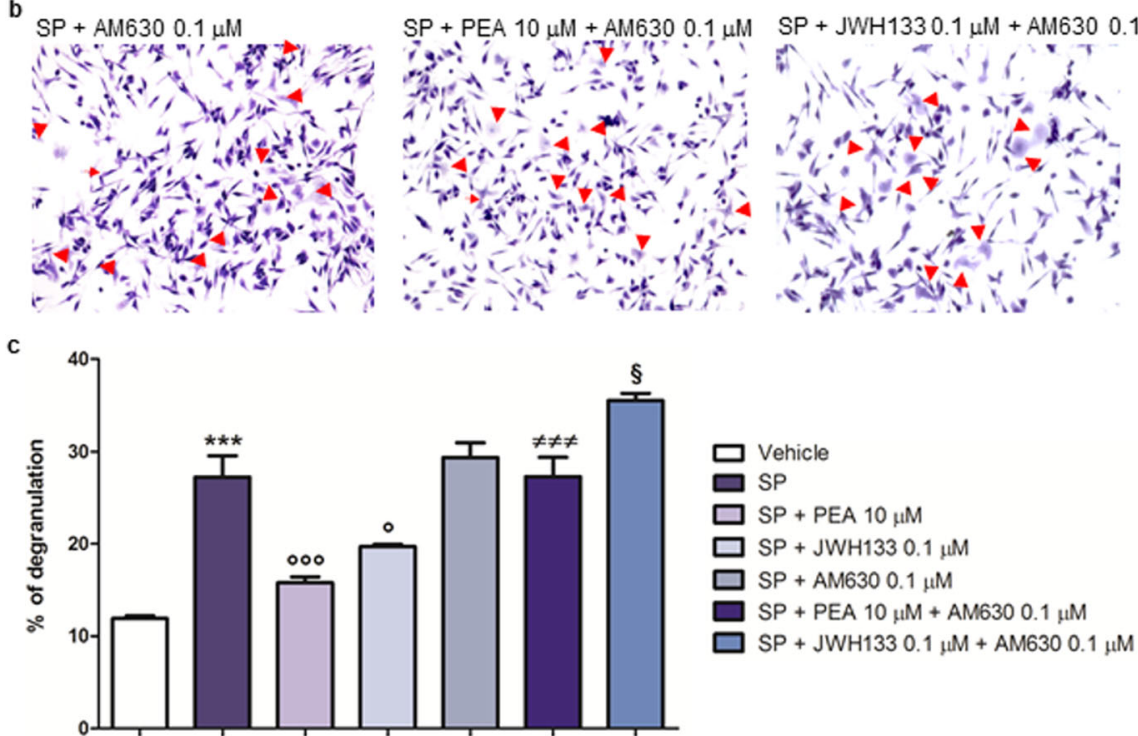

Fig. 4 PEA and JWH133 down-modulate SP-induced degranulation of RBL-2H3 cells via a CB2-mediated mechanism. Toluidine blue staining was performed to measure the number of degranulated RBL-2H3 cells after that a RBL-2H3 cells were stimulated with SP $(10 \mu \mathrm{M})$ in the presence and absence of PEA $(10 \mu \mathrm{M})$, or JWH133 $(0.1 \mu \mathrm{M})$, for $15 \mathrm{~min}$ at $37^{\circ} \mathrm{C}$ in a $5 \% \mathrm{CO}_{2}$ atmosphere; b SP-stimulated RBL-2H3 cells were treated with AM630 $(0.1 \mu \mathrm{M})$, in the presence and absence of PEA $(10 \mu \mathrm{M})$, or JWH133 $(0.1 \mu \mathrm{M})$, for the indicated time. Red arrows show degranulated RBL$2 \mathrm{H} 3$ cells. c Percentage of degranulation. Each bar shows the mean \pm SEM. ${ }^{* * *} p<0.001$ compared with vehicle. ${ }^{\circ} p<0.05$ and ${ }^{000} p<0.001$ compared with SP. ${ }^{\neq \neq \neq} p<0.001$ compared with SP + PEA $10 \mu \mathrm{M} .{ }^{\S} p<0.05$ compared with SP + JWH133 $0.1 \mu \mathrm{M}$

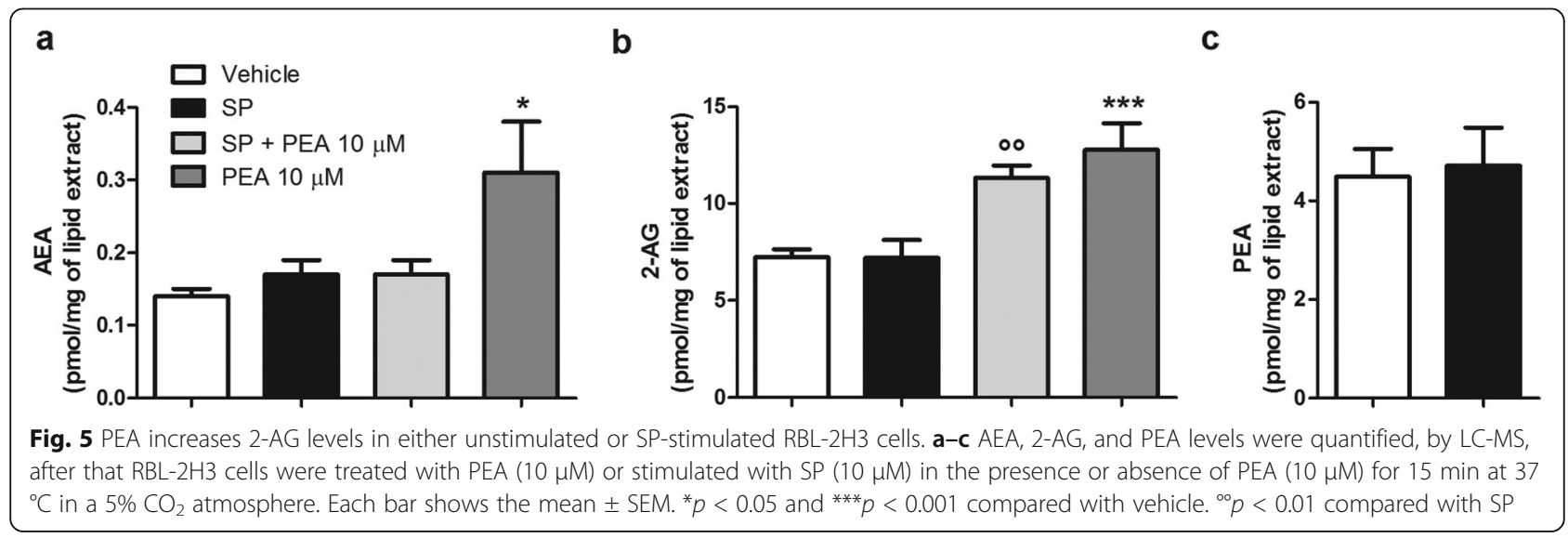


cells (Fig. 5b). It is noteworthy that, considering that $1 \mathrm{mg}$ of lipids are usually extracted from $10 \mathrm{mg}$ of cell pellet (personal communication by Petrosino $S$ and Di Marzo V), i.e., a volume of $10 \mu \mathrm{l}$, the concentration of 2-AG in SP-stimulated RBL-2H3 cells treated with PEA $(10 \mu \mathrm{M})$ can be estimated to be about $1.2 \mu \mathrm{M} v s .0 .7 \mu \mathrm{M}$ in unstimulated cells, pointing to an increase of $0.5 \mu \mathrm{M}$, which is sufficient to fully activate CB2. Finally, no statistically significant increase of the endogenous levels of AEA was observed when SP-stimulated RBL-2H3 cells were treated with PEA $(10 \mu \mathrm{M})$, as compared to SP-stimulated RBL-2H3 cells treated with PEA vehicle (Fig. 5a). In contrast, a statistically significant increase of the endogenous levels of AEA was observed when unstimulated RBL-2H3 cells were treated with PEA alone $(10 \mu \mathrm{M})$, as compared to vehicle-treated RBL-2H3 cells (Fig. $5 \mathrm{a}$ ).

PEA does not modulate the mRNA expression of its targets, nor that of its or 2-AG biosynthetic and catabolic enzymes

In unstimulated RBL-2H3 cells, we found a robust mRNA expression of Napepld and Naaa (Fig. 6a, b), whereas less robust mRNA expression of Cnr2, Daglb, Faah, and $M g l$ (Fig. 6a, b) was found (Table 2). RBL$2 \mathrm{H} 3$ cells stimulated (for $15 \mathrm{~min}$ ) with either SP $(10 \mu \mathrm{M})$ or PEA $(10 \mu \mathrm{M})$ or both showed no statistically significant change in the expression of the mRNAs encoding for these receptors and enzymes (Fig. 6a, b). A very low expression of Cnr1 and no expression of Trpv1, Ppara, Gpr55, and Dagla was found in either unstimulated or SP-stimulated RBL-2H3 cells, treated or untreated with PEA (data not shown).

\section{Lack of significant effects of PEA on the binding and functional activity of 2-AG at the human recombinant CB2 receptor}

Binding data indicated that 2-AG alone showed highbinding affinity for CB2 $\left(K_{i}=0.07 \pm 0.01 \mu \mathrm{M}\right)$ (Fig. 7a), whereas PEA alone did not show a measurable affinity for this receptor $\left(K_{i}>10 \mu \mathrm{M}\right)$ (Fig. 7a). When 2-AG was co-incubated with the two lowest concentrations tested of PEA ( 1 and $5 \mu \mathrm{M})$, its binding affinity did not statistically change $\left(K_{i}=0.06 \pm 0.01\right.$ and $0.07 \pm 0.01 \mu \mathrm{M}$,
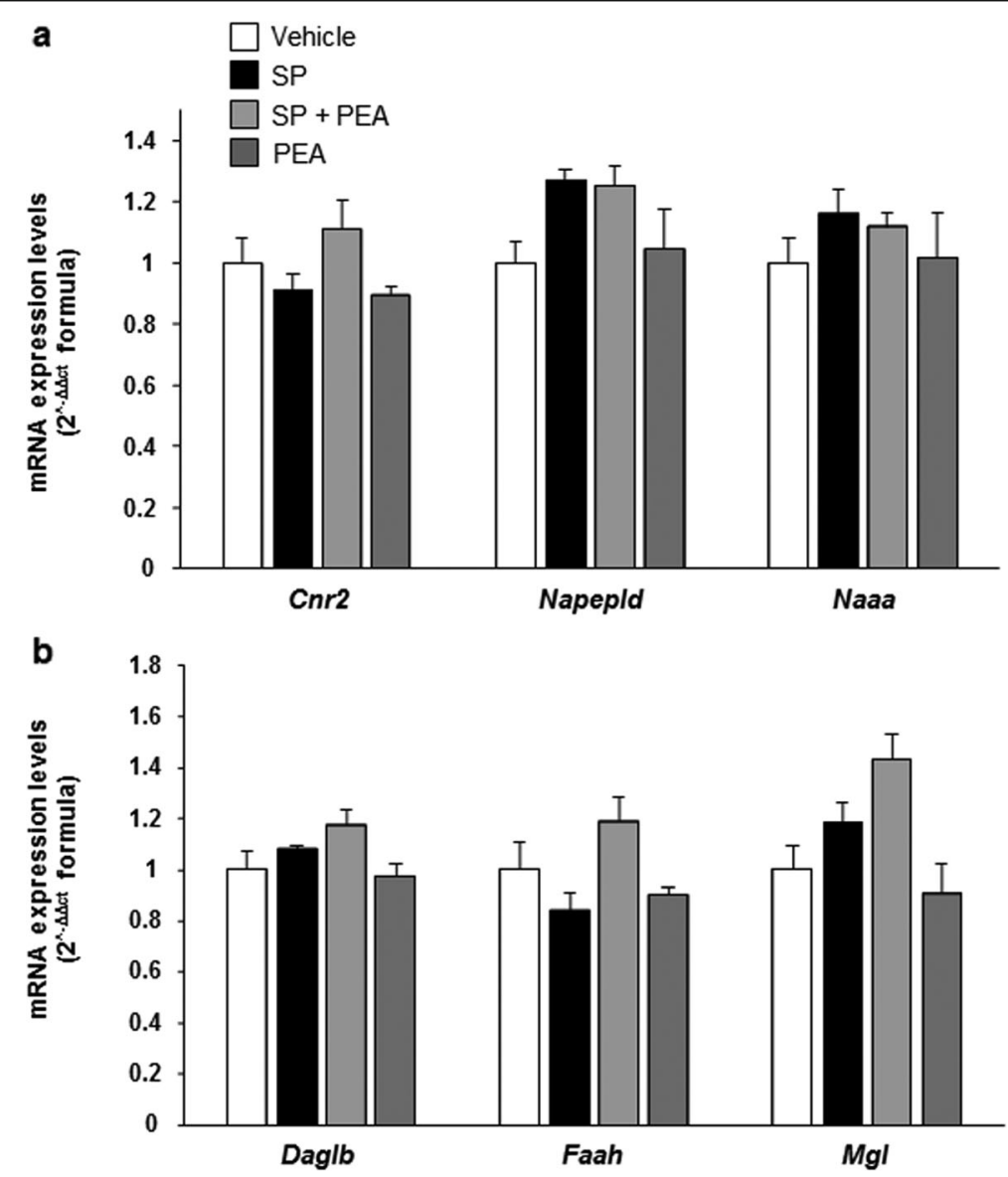

Fig. 6 Effect of PEA on mRNA expression levels of PEA and 2-AG receptors and metabolic enzymes. Real-time qPCR analysis showing the transcript levels of a Cnr2, Napepld, and Naaa; and b Daglb, Faah, and Mgl, in RBL-2H3 cells treated with PEA (10 $\mu$ M) or stimulated with SP (10 $\mu \mathrm{M})$ in the presence or absence of PEA $(10 \mu \mathrm{M})$, for $15 \mathrm{~min}$ at $37^{\circ} \mathrm{C}$ in a $5 \% \mathrm{CO}_{2}$ atmosphere. Each bar shows the mean \pm SEM 
Table 2 mRNA expression levels of PEA and 2-AG receptors and metabolic enzymes

\begin{tabular}{ll}
\hline Gene & CT values \pm SD \\
\hline Cnr1 & $30.95 \pm 0.39$ \\
Cnr2 & $26.45 \pm 0.22$ \\
Trpv1 & N.D. \\
Ppara & N.D. \\
Gpr55 & N.D. \\
Napepld & $23.76 \pm 0.09$ \\
Dagla & N.D. \\
Daglb & $26.98 \pm 0.10$ \\
Faah & $26.91 \pm 0.21$ \\
Naaa & $24.30 \pm 0.12$ \\
Mgl & $26.77 \pm 0.09$ \\
B-actin & $14.98 \pm 0.15$ \\
HPRT & $21.91 \pm 0.18$ \\
\hline
\end{tabular}

respectively) (Fig. 7a). However, when 2-AG was incubated with the highest concentration tested of PEA (10 $\mu \mathrm{M})$, we found a significant improvement of its binding affinity $\left(K_{i}=0.02 \pm 0.005 \mu \mathrm{M}\right)$ (Fig. 7a), which however appeared to be due to the little effect on $\left[{ }^{3} \mathrm{H}\right]-\mathrm{CP} 55,940$ displacement exerted per se by PEA $(10 \mu \mathrm{M})(33.51 \pm$ 5.28\%) (Fig. 7a).

PEA did not activate CB2 since, at the highest concentration tested $(10 \mu \mathrm{M})$, it failed at decreasing cAMP levels under the stimulus of NKH-477 (Fig. 7b). On the contrary, 2-AG in a concentration-dependent manner reduced NKH-477-induced cAMP levels $\left(\mathrm{IC}_{50}=590 \pm\right.$ $160 \mathrm{nM})$. The presence of PEA $(10 \mu \mathrm{M})$ slightly decreased 2-AG efficacy $\left(\mathrm{IC}_{50}=1988 \pm 220 \mathrm{nM}\right)$, although in a non-statistically significant manner, and enhanced the effect only of the lowest concentration of 2-AG tested (10 nM) (Fig. 7b).

\section{PEA stimulates the activity of DAGL- $\alpha$ and $-\beta$ and the biosynthesis of 2-AG in COS-7 cells over-expressing DAGL-a}

PEA stimulated DAGL- $\alpha$ activity with an $\mathrm{EC}_{50}$ value of $17.3 \pm 2.35 \mu \mathrm{M}$ (Fig. 8a), in COS-7 cells overexpressing DAGL- $\alpha$. PEA also stimulated the activity of DAGL- $\beta$ by $33 \pm 5.43 \%$ at the concentration of 25 $\mu \mathrm{M}$ (Fig. 8b), in RBL-2H3 cells. Importantly, the stimulatory effect of PEA $(25 \mu \mathrm{M})$ on RBL-2H3 cell DAGL- $\beta$ activity was comparable to that observed with $\mathrm{Ca}^{2+}(10 \mathrm{mM})$ (Fig. 8b). Instead, PEA exhibited no inhibitory effect on MGL activity up to $25 \mu \mathrm{M}$ (the maximal \% inhibition was calculated to be $<5 \%$ ).

We also measured by LC-MS the levels of 2-AG produced after enzymatic hydrolysis of the substrate 1-oleoyl-2-arachidonoylglycerol by DAGL- $\alpha$, in the presence or absence of PEA $(25 \mu \mathrm{M})$. The analysis revealed that when membrane preparations obtained from COS-7 cells over-expressing DAGL- $\alpha$ were incubated with the substrate 1-oleoyl-2-arachidonoylglycerol, the levels of 2-AG were significantly increased by 3.9 -fold compared to membrane preparations incubated in the absence of the substrate (Fig. 8c). PEA $(25 \mu \mathrm{M})$ was able to significantly further elevate the levels of 2-AG: i) by 1.4-fold compared to membrane preparations incubated with the substrate and without PEA; and ii) by 5.6 -fold compared to membrane preparations incubated alone, i.e., in the absence of both the substrate and PEA (Fig. 8c).
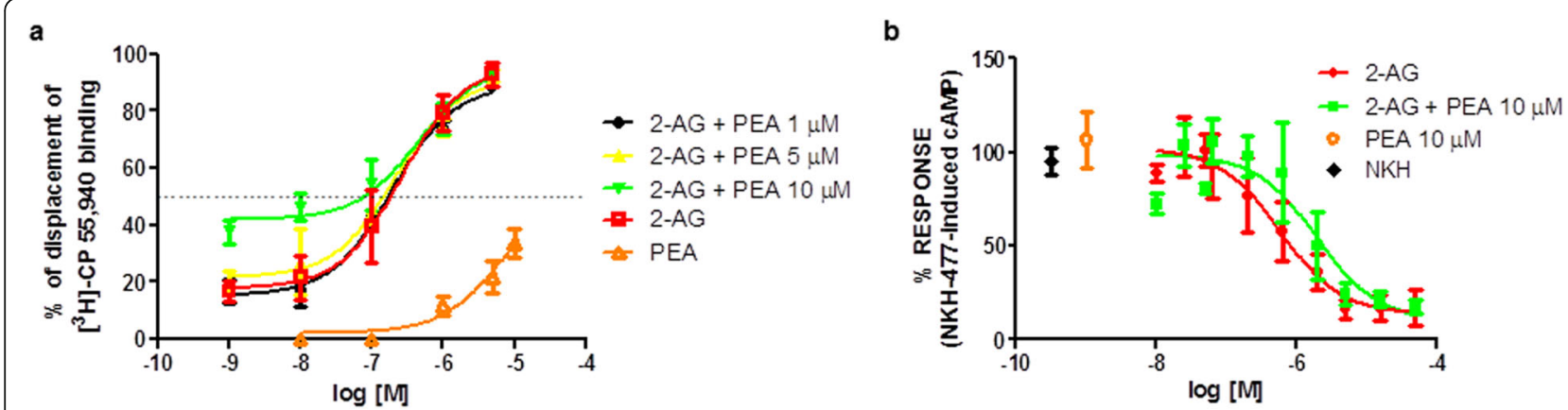

Fig. 7 Effects of PEA on 2-AG affinity and efficacy at the human CB2 receptor. a Displacement curves of 2-AG and PEA, alone and in combination, in a competition binding assay. The curves show the effect of increasing concentrations of 2-AG, PEA, or 2-AG plus PEA at displacing $\left[{ }^{3} \mathrm{H}\right]-\mathrm{CP}-55,940$ from the human recombinant CB2. All experiments were performed in membranes from HEK-293 cells overexpressing the human recombinant CB2 receptors. Data are the mean \pm SEM. The effect of WIN55, 212-2 (10 $\mu \mathrm{M})$ was considered as 100\% displacement. b Concentration-response curves of 2-AG and PEA, alone and in combination, in a CAMP-based functional assay. The curves show the \% of the response relative to the maximum effect observed on NKH-477-induced CAMP levels in CHO-KI cells stably overexpressing the human recombinant CB2 receptor with increasing concentrations of 2-AG, PEA, or 2-AG following incubation with PEA. 
a

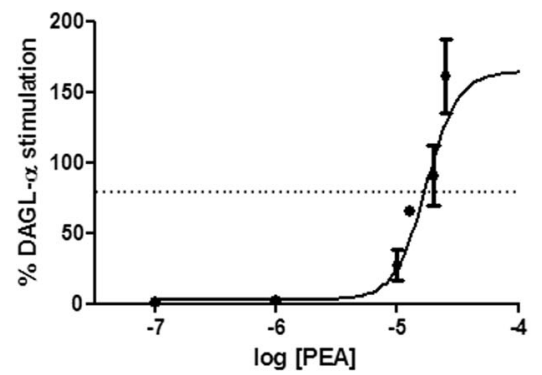

c

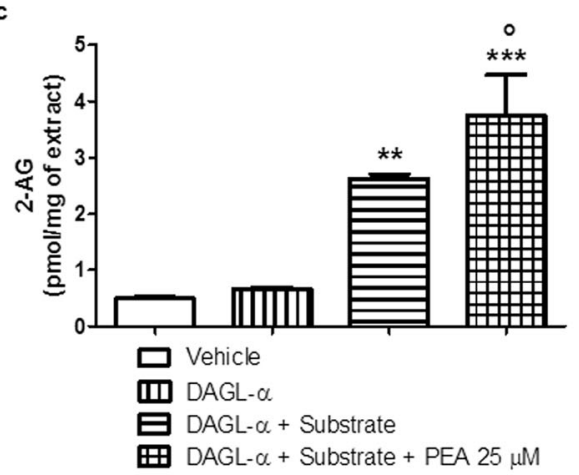

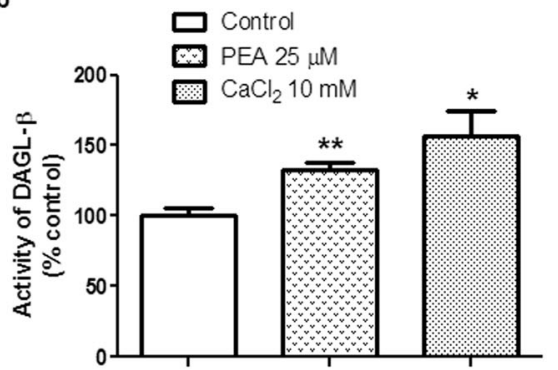

d

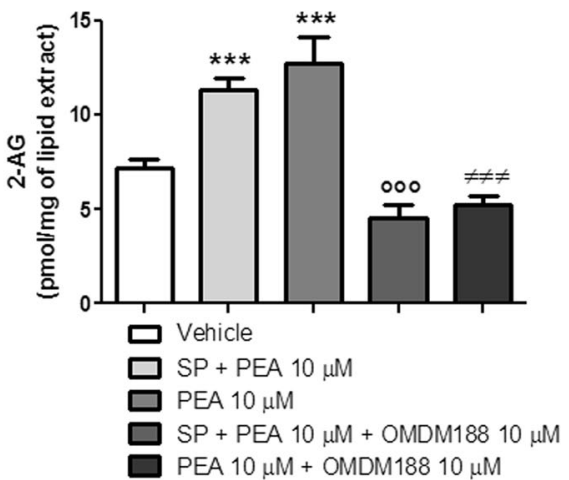

Fig. 8 PEA stimulates DAGL- $a$ and $-\beta$. a Concentration-response curve for the stimulation of DAGL-a activity by PEA. The curve shows the \% of stimulation compared to the activity of the enzyme with no PEA, observed with increasing concentrations of PEA in membranes obtained from COS-7 cells over-expressing human recombinant DAGL-a. Data are the means \pm SEM. $\mathbf{b}$ Effect of PEA $(25 \mu \mathrm{M})$ and CaCl 2 (10 mM) on DAGL- $\beta$ activity in RBL-2H3 cell membranes. Data are the means \pm SEM. ${ }^{*} p<0.05$ and ${ }^{* *} p<0.01$ compared with Control. c The levels of 2-AG by LC-MS were measured after that membrane preparations (70 $\mu \mathrm{g}$ of protein) from COS-7 cells over-expressing DAGL-a were incubated with 1-oleoyl-2arachidonoylglycerol $(25 \mu \mathrm{M})$ in the presence or absence of PEA $(25 \mu \mathrm{M})$ for $20 \mathrm{~min}$ at $37^{\circ} \mathrm{C}$, i.e., using the same conditions for enzyme activity assay as in $\mathbf{a}$. Each bar shows the mean \pm SEM. ${ }^{* *} p<0.01$ and ${ }^{* * *} p<0.001$ compared with DAGL-a. ${ }^{\circ} p<0.05$ compared with DAGL-a + substrate. $\mathbf{d}$ The endogenous levels of 2-AG were measured after that RBL-2H3 cells were treated with PEA (10 $\mu \mathrm{M})$ in the presence or absence of the DAGL inhibitor, OMDM188 $(10 \mu \mathrm{M})$, or stimulated with SP $(10 \mu \mathrm{M})$ and treated with PEA $(10 \mu \mathrm{M})$ in the presence or absence of OMDM188 $(10$ $\mu \mathrm{M})$, for $15 \mathrm{~min}$ at $37^{\circ} \mathrm{C}$ in a $5 \% \mathrm{CO}_{2}$ atmosphere. Each bar shows the mean \pm SEM. ${ }^{* * *} p<0.001$ compared with vehicle. ${ }^{000} p<0.001$ compared with SP + PEA $10 \mu \mathrm{M} .{ }^{\neq \neq \neq} p<0.001$ compared with PEA $10 \mu \mathrm{M}$. Vehicle, SP + PEA $10 \mu \mathrm{M}$ and PEA $10 \mu \mathrm{M}$ data are the same as in Fig. 5b

OMDM188 blocks the stimulatory effect of PEA on 2-AG levels in both untreated and SP-treated RBL-2H3 cells The analysis by LC-MS revealed that when SPstimulated RBL-2H3 cells (10 $\mu \mathrm{M}$ for $15 \mathrm{~min})$ were treated with OMDM188 $(10 \mu \mathrm{M})$, a DAGL inhibitor [43], in the presence of PEA $(10 \mu \mathrm{M})$, the endogenous levels of 2-AG were decreased by 2.5 -fold compared to SP-stimulated RBL-2H3 cells treated only with PEA (Fig. 8d). Likewise, when unstimulated RBL-2H3 cells were treated with OMDM188 $(10 \mu \mathrm{M})$ in the presence of PEA $(10 \mu \mathrm{M})$, the endogenous levels of 2-AG were decreased by 2.4-fold compared to unstimulated RBL-2H3 cells treated with PEA $(10 \mu \mathrm{M})$ alone (Fig. 8d).

\section{OMDM188 blocks the effect of PEA on SP-induced} histamine release and degranulation in RBL-2H3 cells When SP-stimulated RBL-2H3 cells (10 $\mu \mathrm{M}$ for $15 \mathrm{~min})$ were treated with OMDM188 $(10 \mu \mathrm{M})$ in the presence of PEA $(10 \mu \mathrm{M})$, histamine release (Fig. 9a) and the number of degranulated RBL-2H3 cells (Fig. 9b, c) were comparable to that observed in SP-stimulated RBL-2H3 cells treated with the vehicle, i.e., in the absence of both OMDM188 and PEA (Fig. 9).

PEA and 2-AG synergize at down-modulating SP-induced histamine release and degranulation in RBL-2H3 cells

When SP-stimulated RBL-2H3 cells $(10 \mu \mathrm{M}$ for $15 \mathrm{~min})$ were treated with either PEA or 2-AG, both at the lowest concentration tested $(0.1 \mu \mathrm{M})$, histamine release (Fig. 10a) and degranulation (Fig. 10b, c) were comparable to that observed in SP-stimulated RBL-2H3 cells treated only with the vehicle (Fig. 10). By contrast, 2AG at the highest concentration tested $(1 \mu \mathrm{M})$, like PEA $(10 \mu \mathrm{M})$, was able to reduce SP-induced histamine release (Fig. 10a) and degranulation (Fig. 10b, c) in RBL-2H3 cells, as compared to SP-stimulated RBL-2H3 cells treated only with vehicle (Fig. 10). Co-treatment 


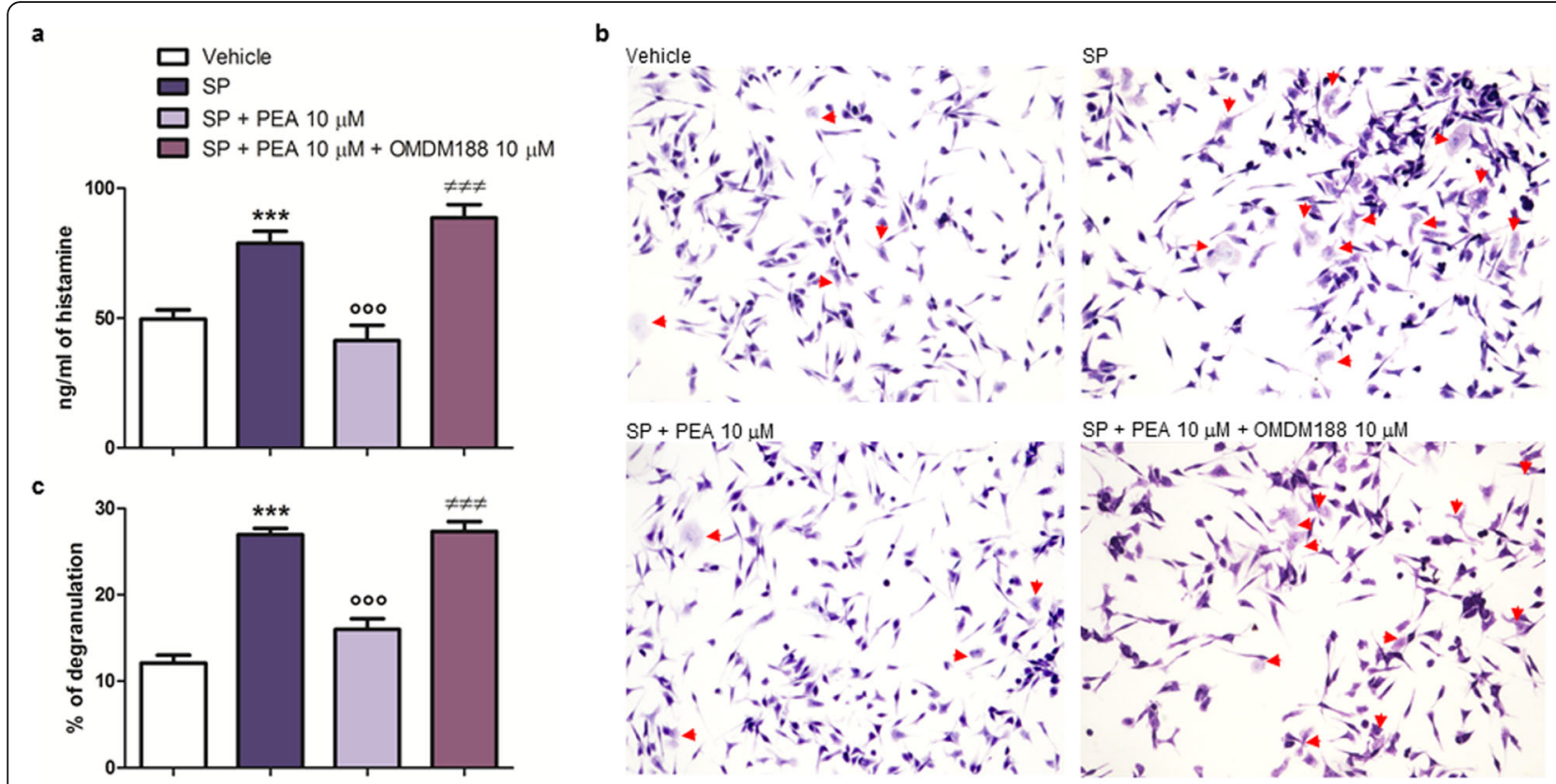

Fig. 9 OMDM188 blocks PEA down-modulation of SP-induced histamine release and degranulation in RBL-2H3 cells. a Histamine release by ELISA, $\mathbf{b}$ Toluidine blue staining, and $\mathbf{c}$ the percent of degranulation were measured after that RBL-2H3 cells were stimulated with SP (10 $\mu \mathrm{M})$ and treated with PEA $(10 \mu \mathrm{M})$ in the presence or absence of OMDM188 $(10 \mu \mathrm{M})$ for $15 \mathrm{~min}$ at $37^{\circ} \mathrm{C}$ in a $5 \% \mathrm{CO}_{2}$ atmosphere. Absorbance was measured at $450 \mathrm{~nm}(\mathbf{a})$. Red arrows show degranulated RBL-2H3 cells (b). Each bar (a, c) shows the mean \pm SEM. ${ }^{* *} p<0.001$ compared with vehicle. ${ }^{000} p<0.001$ compared with SP. ${ }^{\neq \neq \neq} p<0.001$ compared with SP + PEA $10 \mu \mathrm{M}$

with PEA and 2-AG, both at the per se ineffective concentration of $0.1 \mu \mathrm{M}$, was able to reduce the release of histamine (Fig. 10a) and the number of degranulated cells (Fig. 10b, c) from SP-stimulated RBL-2H3 cells, as compared to SP-stimulated RBL-2H3 cells treated with the highest concentration tested of PEA $(10 \mu \mathrm{M})$ or 2AG $(1 \mu \mathrm{M})$ (Fig. 10).

\section{Discussion}

$\mathrm{NI}$ is a well-known process participating in the pathogenesis of several diseases of the nervous and respiratory systems, gastrointestinal and urogenital tracts, and skin [44]. It is elicited by the release of potent pro-algesic and inflammatory mediators, among which the neuropeptides SP and calcitonin gene-related peptide, from sensory

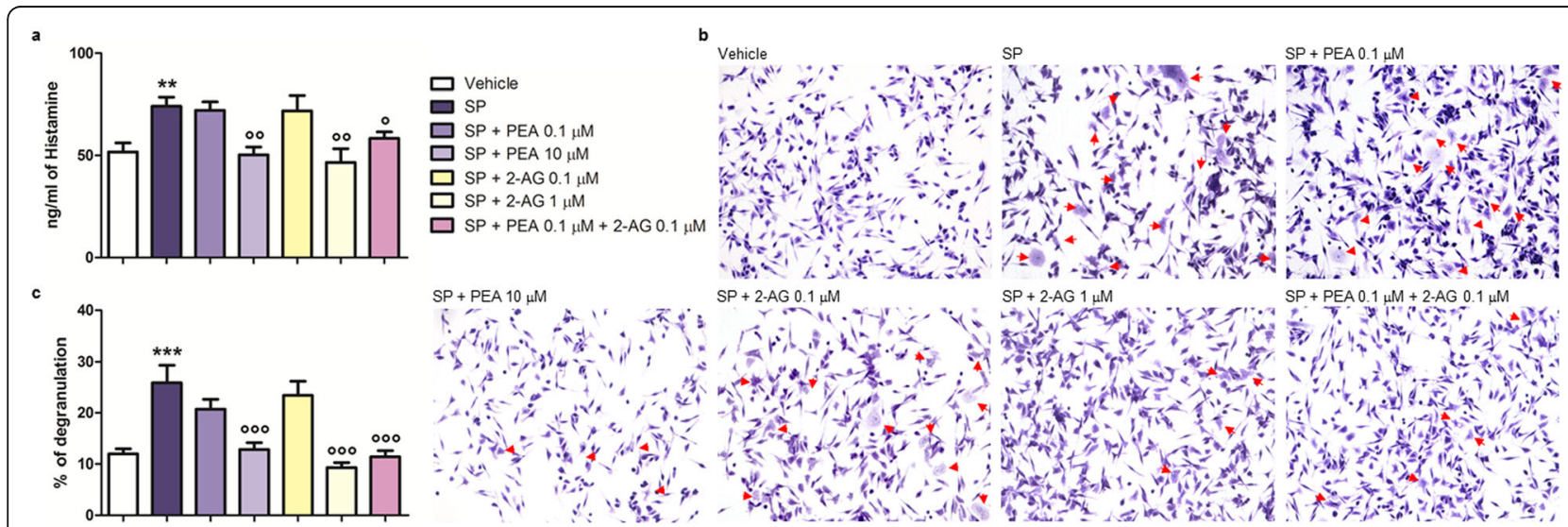

Fig. 10 Co-treatment with subeffective concentrations of PEA and 2-AG down-modulates SP-induced histamine release and degranulation in $\mathrm{RBL}-2 \mathrm{H} 3$ cells. a Histamine release by ELISA, $\mathbf{b}$ Toluidine blue staining, and $\mathbf{c}$ the percent of degranulation were measured after that RBL-2H3 cells were stimulated with SP $(10 \mu \mathrm{M})$ and treated with PEA (0.1 and $10 \mu \mathrm{M})$, 2-AG (0.1 and $1 \mu \mathrm{M})$, or PEA (0.1 $\mu \mathrm{M})$ plus 2 -AG (0.1 $\mu \mathrm{M})$, for 15 min at 37 ${ }^{\circ} \mathrm{C}$ in a $5 \% \mathrm{CO}_{2}$ atmosphere. Absorbance was measured at $450 \mathrm{~nm}$ (a). Red arrows show degranulated RBL-2H3 cells (b). Each bar (a, c) shows the mean \pm SEM. ${ }^{* *} p<0.01$ and ${ }^{* * *} p<0.001$ compared with vehicle. ${ }^{\circ} p<0.05,{ }^{\circ} p<0.01$, and ${ }^{\circ 00} p<0.001$ compared with SP 
nerve fibers (particularly C-fibers) afferent to the skin, and respiratory, intestinal and urinary tissues [44]. Once released, the neuropeptides trigger a cascade of inflammatory responses including the degranulation of adjacent $\mathrm{MC}$, and hence the release of pre-formed mediators, among which histamine, from MC granules [44]. MC are a key player in the immune system exerting both a regulatory role, in as much as they are capable of suppressing the inflammatory processes [45], and an effector role when deregulated, such as, for example, during NI, when they exacerbate the progression of the inflammatory disease [45]. NI is currently viewed as a common substrate for different diseases [46-49].

PEA, a lipid produced on demand in many animal cells and tissues, acts as a balancer in those disorders associated with neuroinflammation by suppressing the pathological consequences triggered by over-stimulated $\mathrm{MC}$ $[2,4,9,10]$. In fact, PEA is able to downmodulate MC activation and degranulation by reducing the release of $\beta$-hexosaminidase and serotonin induced by IgE receptor crosslinking in RBL-2H3 cells [27, 50], as well as the amount of degranulation and subsequent plasma extravasation induced by SP injection in the mouse ear pinna [29]. CB2 receptors were initially suggested to be involved in most of these effects of PEA, which, accordingly, were attenuated by the CB2 antagonist SR144528 $[27,51]$, as were other reported anti-inflammatory and analgesic actions of this lipid [52, 53]. Later, it was clearly demonstrated that PEA exhibits only very weak activity at CB2 receptors [12], and as a result several hypotheses on its mechanism of action were developed [2, 4]. One of these is known as entourage effect and had been earlier on proposed to underlie also the cannabimimetic effect of non-cannabinoid receptor active monoacylglycerol homologs of 2-AG [17]. It consists in the capability of PEA to potentiate the signaling of endocannabinoids and endovanilloids at CB1 and CB2 receptors or TRPV1 channels, through several receptor- (PPAR $\alpha$, GPR55) and non-receptor-mediated mechanisms, and has gained increasing evidence over the last 20 years [13, 18-20, 22, 23, 25, 26]. Nevertheless, before the present study, the entourage effect of PEA had never been extended to the very first reported example of PEA antiinflammatory effects, i.e., its capability of downregulating MC hyperactivity [27]. Here we demonstrate for the first time that this very important protective action of PEA, described here to occur also in what could be considered a simplified in vitro model of NI, is due to a direct stimulatory effect of the lipid on 2-AG biosynthesizing enzymes, the DAGLs $\alpha$ and $\beta$, and the subsequent elevation of cellular 2-AG concentrations.

We used the widely employed RBL-2H3 cell line as a MC model. Indeed, following incubation with SP, these cells undergo degranulation and released $\beta$-hexosaminidase and histamine into the extracellular medium. In agreement with its previously described MC stabilizing effect [27], we first found that PEA dose-dependently down-modulates SPinduced degranulation of RBL-2H3 cells and the release therefrom of $\beta$-hexosaminidase and histamine. We then assigned these effects of PEA exclusively to its ability to reduce the response to SP stimulation, inasmuch as we showed that neither SP stimulation nor PEA treatment affected the viability and cytotoxicity of RBL-2H3 cells. More importantly, we confirmed that these effects were due to activation of CB2, as shown not only by the fact that they were blocked by a selective CB2 receptor antagonist, used at a concentration selective vs. CB1 receptors, but also by the finding that the synthetic CB2 agonist could reproduce them in a CB2 antagonist-sensitive manner. Importantly, in agreement with previous data [27], we found that RBL-2H3 cells do express $\mathrm{CB} 2$, but very little $\mathrm{CB} 1$, receptors. We also showed that other direct targets suggested for PEA, i.e., PPAR $\alpha$ and GPR55, are not expressed in these cells. Unsurprisingly, this receptor expression profile did not change following short-term stimulation of the cells with either SP or PEA or both.

These findings directed our subsequent experiments, with the aim of investigating the mechanism by which PEA may exert a CB2-dependent effect, since, as confirmed also by our present findings (Fig. 7), this lipid mediator is only very weakly active per se at CB2 receptors. We hypothesized that PEA was acting by elevating the levels of endogenous CB2 agonists, as previously found in vitro, in some cell types, as well as in vivo, in dogs and humans (see above). To date, only the two endocannabinoids, AEA and 2-AG, have been identified as endogenous agonists of CB2 and, of these two compounds, only 2-AG is known to act as a full agonist of this receptor [33], thereby producing inflammation and pain modulatory effects both in vivo, such as for example in ACD [16] and in a model of NI-induced pain [54], and in vitro [55]. Thus, we hypothesized that endogenous 2-AG could play a role in the indirect CB2mediated mechanism of action of PEA. Accordingly, we measured the levels of AEA and 2-AG in unstimulated RBL-2H3 cells and found that they were increased by 2-fold following PEA treatment, in agreement with our previous data on increased levels of AEA and 2-AG by PEA in other cell types $[19,20]$.

It is known that the activation of the neurokinin-1 receptor by its agonists, such as SP, induces activation of phospholipase $\mathrm{C}$, with subsequent hydrolysis of phosphoinositides into inositol 1,4,5-triphosphate and diacylglycerol [56], which acts as a biosynthetic precursor of 2-AG [4]. Therefore, we speculated that SP-stimulation of RBL-2H3 cells could also induce an increase of endogenous levels of 2-AG. However, we found that PEA increased by $\sim 2$-fold the amounts of 2-AG also in SP- 
stimulated RBL-2H3 cells and that, instead, the amounts of 2-AG did not change following stimulation of RBL$2 \mathrm{H} 3$ cells with SP alone. This indicates that the higher levels of 2-AG measured in SP-stimulated RBL-2H3 cells treated with PEA were due only to treatment with PEA, which possibly triggered events down-stream to phospholipase $\mathrm{C}$ activation, such as, for example, the stimulation of DAGL- $\beta$ activity in these cells (which do not express DAGL- $\alpha$ ), or the inhibition of 2-AG enzymatic degradation. In addition, we found that AEA concentrations did not change in either RBL-2H3 cells only stimulated with SP or SP-stimulated RBL-2H3 cells treated with PEA.

In support of the hypothesis that elevation of 2-AG biosynthesis was both necessary and sufficient to PEA to exert its effects against SP-induced RBL-2H3 cell degranulation, we showed that an inhibitor of DAGLs prevented both PEA stimulation of 2-AG levels and PEA inhibition of degranulation. Furthermore, we found that, in cell-free systems, PEA, at concentrations similar to those necessary to exert the above effects, activated both constitutive DAGL- $\beta$ activity in RBL-2H3 cell membranes, and human recombinant DAGL- $\alpha$ overexpressed in membranes from COS-7 cells. The effect of PEA on DAGL- $\alpha$ activity in these cells was confirmed by the finding of the significantly increased amounts of 2-AG produced from the enzymatic hydrolysis of the substrate, 1-oleoyl-2-arachidonoylglycerol, in a cell-free system used in the assay of DAGL- $\alpha$, as assessed by LC-MS. By converse, PEA, at the same concentrations, did not affect MGL activity. Finally, we found that 2-AG, at a concentration of $1 \mu \mathrm{M}$, which is not different from that found here in PEA + SP-stimulated RBL-2H3 cells, was able to mimic the MC down-modulating effects of PEA, and, at a subeffective concentration synergized with a subeffective concentration of PEA at producing these effects. These results suggest that PEA is an endogenous activator of 2-AG biosynthesis via the DAGLs, and in particular of DAGL $\beta$, in RBL-2H3 cells, where 2-AG acts as an intermediate of PEA actions.

Previous studies in different models of MC stimulation had shown that (1) 2-AG decreases the immunological activation of guinea pig $\mathrm{MC}$ via $\mathrm{CB} 2$ receptors [57]; (2) PEA produces a small, but significant reduction in IgE/ antigen-stimulated serotonin release at high concentrations, whereas AEA is without effect and 2-AG exerts the opposite effect [46]; (3) AEA inhibits IgE/antigen-induced degranulation of murine bone marrow-derived MC via CB2 and GPR55 receptor activation [58]; and (4) PEA inhibits phorbol ester-induced nerve growth factor release from the HMC-1 MC line via activation of GPR55 [59]. These studies indicate that PEA, 2-AG and AEA may affect in a different manner and via different mechanisms the stability of MC treated with different stimuli, in contexts different from NI, possibly also depending on the PEA receptor expression profile of the cell model used; profile that, in turn, may be modified by mRNA expression modifying stimuli (such as IgE/ antigen and phorbol esters) more than by acute treatment with SP, as shown here.

We also investigated whether or not PEA affects the activity, and not only the levels, of 2-AG at CB2 receptors. Using preparations overexpressing the human recombinant $\mathrm{CB} 2$, we found that PEA, at the highest concentration tested (which corresponded with the efficacious in vitro concentration, $10 \mu \mathrm{M}$ ), appeared capable to improve the binding affinity of $2-\mathrm{AG}$ and its efficacy in a functional assay only when the endocannabinoid was incubated at nanomolar and almost inactive concentrations. However, while the effect on binding was probably an artifact due to the slight activity exerted by PEA in this assay, the effect on efficacy was likely not biologically significant in the context of the present study, given the fact that 2-AG concentrations in unstimulated and stimulated RBL-2H3 cells were found here to be in the low $\mu \mathrm{M}$ range.

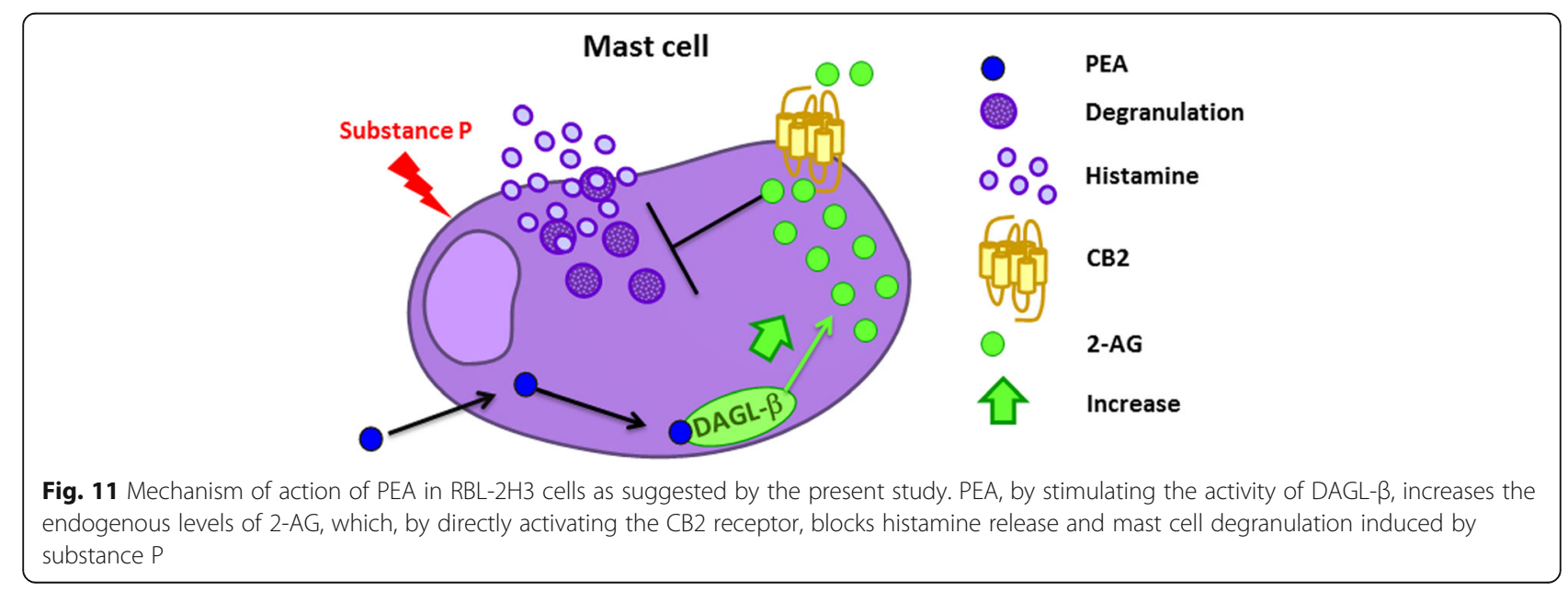




\section{Conclusions}

In summary, we have demonstrated for the first time that short-term treatment with PEA enhances the biosynthesis of 2 -AG by stimulating DAGL- $\alpha$ or $-\beta$ enzyme activity (see the scheme in Fig. 11 for the proposed PEA mechanism of action). Apart from explaining at last the pioneering report of PEA down-regulation of $\mathrm{MC}$ hyperactivity [27], this novel mechanism may underlie also the previously described stimulatory effect of orally administered ultra micronized or micronized PEA on 2-AG levels in dogs or humans, respectively [20]. It also suggests that such formulations of PEA may synergize with endogenous 2-AG to modulate NI, as well as other inflammatory processes regulated by the endocannabinoid in blood cells (see [60] for review), via a CB2-mediated mechanism.

\section{Abbreviations}

2-AG: 2-Arachidonoylglycerol; AEA: Anandamide; CB2: Cannabinoid receptor type-2; Dagl: Diacylglycerol lipase; Faah: Fatty acid amide hydrolase; MC: Mast cells; Mgl: Monoacylglycerol lipase; Naaa: N-acylethanolaminehydrolyzing acid amidase; Napepld: N-acyl phosphatidylethanolaminespecific phospholipase D; NI: Neurogenic inflammation;

PEA: Palmitoylethanolamide; PPARa: Peroxisome proliferator-activated nuclear receptor-a; SP: Substance P; TRPV1: Transient receptor potential vanilloid type-1

\section{Acknowledgements}

Not applicable.

\section{Authors' contributions \\ SP and VD conceived and designed the study. SP, ASM, AL, and FAI analyzed the data. ASM and FAl performed the GPCR analysis. SP and RV performed most experiments, the ELISA assay and LC-MS analysis. MA performed the binding and enzymatic assays. RI performed the toluidine blue staining tech- nique. AMM performed the CB2 functional assay. AFP performed the extrac- tion and purification techniques. SP and VD wrote the manuscript. All authors read and approved the final manuscript.}

\section{Funding}

This study was supported by Progetto Operativo Nazionale (PON01_02512) and by the project PO FESR 2007/2013 "BANDO PER LA REALIZZAZIONE DELLA RETE DELLE BIOTECNOLOGIE IN CAMPANIA" PROGETTO "Terapie Innovative di Malattie Infiammatorie croniche, metaboliche, Neoplastiche e Geriatriche-TIMING".

\section{Availability of data and materials}

Data generated and analyzed as part of this study are included in the manuscript or are available upon request from the corresponding author.

\section{Ethics approval and consent to participate} Not applicable.

\section{Consent for publication}

Not applicable.

\section{Competing interests}

SP, ASM, and MA are employees of Epitech Group SpA. VD is co-inventor on patents on PEA. The other authors declare that they have no conflict of interest.

\section{Author details}

${ }^{1}$ Endocannabinoid Research Group, Istituto di Chimica Biomolecolare Consiglio Nazionale delle Ricerche, Via Campi Flegrei 34, 80078 Pozzuoli (Napoli), Italy. ${ }^{2}$ Epitech Group SpA, Via Einaudi 13, 35030, Saccolongo (Padova), Italy. ${ }^{3}$ Canada Excellence Research Chair on the
Microbiome-Endocannabinoidome Axis in Metabolic Health, CRIUCPQ and INAF, Faculties of Medicine and Agriculture and Food Sciences, Université Laval, Quebéc City, Canada.

Received: 6 November 2019 Accepted: 9 December 2019

Published online: 26 December 2019

\section{References}

1. Coburn AF, Graham CE, Haninger J. The effect of egg yolk in diets on anaphylactic arthritis (passive Arthus phenomenon) in the guinea pig. J Exp Med. 1954;100:425-35.

2. Petrosino S, Di Marzo V. The pharmacology of palmitoylethanolamide and first data on the therapeutic efficacy of some of its new formulations. $\mathrm{Br}$ J Pharmacol. 2017;174:1349-65.

3. Peritore AF, Siracusa R, Crupi R, Cuzzocrea S. Therapeutic Efficacy of Palmitoylethanolamide and Its New Formulations in Synergy with Different Antioxidant Molecules Present in Diets. Nutrients. 2019;11.

4. lannotti FA, Di Marzo V, Petrosino S. Endocannabinoids and endocannabinoid-related mediators: Targets, metabolism and role in neurological disorders. Prog Lipid Res. 2016;62:107-28.

5. Petrosino S, Cristino L, Karsak M, Gaffal E, Ueda N, Tüting T, et al. Protective role of palmitoylethanolamide in contact allergic dermatitis. Allergy. 2010;65 698-711.

6. Abramo F, Campora L. Albanese F, della Valle MF, Cristino L, Petrosino S, et al. Increased levels of palmitoylethanolamide and other bioactive lipid mediators and enhanced local mast cell proliferation in canine atopic dermatitis. BMC Vet Res. 2014;10:21

7. De Filippis D, D'Amico A, Cipriano M, Petrosino S, Orlando P, Di Marzo V, et al. Levels of endocannabinoids and palmitoylethanolamide and their pharmacological manipulation in chronic granulomatous inflammation in rats. Pharmacol Res. 2010;61:321-8.

8. Petrosino S, Palazzo E, de Novellis V, Bisogno T, Rossi F, Maione S, et al. Changes in spinal and supraspinal endocannabinoid levels in neuropathic rats. Neuropharmacology. 2007;52:415-22

9. Impellizzeri D, Bruschetta G, Cordaro M, Crupi R, Siracusa R, Esposito E, et al. Micronized/ultramicronized palmitoylethanolamide displays superior oral efficacy compared to nonmicronized palmitoylethanolamide in a rat model of inflammatory pain. J Neuroinflammation. 2014;11:136.

10. Impellizzeri et al. The neuroprotective effects of micronized PEA (PEA-m) formulation on diabetic peripheral neuropathy in mice. - PubMed - NCBI [Internet]. 2019 [cited 2019 Nov 26]. Available from: https://www.ncbi.nlm. nih.gov/pubmed/31344333

11. Vaia M, Petrosino S, De Filippis D, Negro L, Guarino A, Carnuccio R, et al. Palmitoylethanolamide reduces inflammation and itch in a mouse model of contact allergic dermatitis. Eur J Pharmacol. 2016;791:669-74.

12. Sugiura T, Kondo S, Kishimoto S, Miyashita T, Nakane S, Kodaka T, et al. Evidence that 2-arachidonoylglycerol but not N-palmitoylethanolamine or anandamide is the physiological ligand for the cannabinoid CB2 receptor. Comparison of the agonistic activities of various cannabinoid receptor ligands in HL-60 cells. J Biol Chem. 2000;275:605-12.

13. De Petrocellis L, Davis JB, Di Marzo V. Palmitoylethanolamide enhances anandamide stimulation of human vanilloid VR1 receptors. FEBS Lett. 2001; 506:253-6.

14. Zygmunt PM, Petersson J, Andersson DA, Chuang H, Sørgård M, Di Marzo V, et al. Vanilloid receptors on sensory nerves mediate the vasodilator action of anandamide. Nature. 1999;400:452-7.

15. Ahern GP. Activation of TRPV1 by the satiety factor oleoylethanolamide. J Biol Chem. 2003;278:30429-34.

16. Karsak M, Gaffal E, Date R, Wang-Eckhardt L, Rehnelt J, Petrosino S, et al. Attenuation of allergic contact dermatitis through the endocannabinoid system. Science. 2007;316:1494-7.

17. Ben-Shabat S, Fride E, Sheskin T, Tamiri T, Rhee MH, Vogel Z, et al. An entourage effect: inactive endogenous fatty acid glycerol esters enhance 2arachidonoyl-glycerol cannabinoid activity. Eur J Pharmacol. 1998;353:23-31.

18. Ho W-SV, Barrett DA, Randall MD. "Entourage" effects of Npalmitoylethanolamide and $\mathrm{N}$-oleoylethanolamide on vasorelaxation to anandamide occur through TRPV1 receptors. Br J Pharmacol. 2008;155:837-46.

19. Di Marzo V, Melck D, Orlando P, Bisogno T, Zagoory O, Bifulco M, et al. Palmitoylethanolamide inhibits the expression of fatty acid amide hydrolase and enhances the anti-proliferative effect of anandamide in human breast cancer cells. Biochem J. 2001;358:249-55. 
20. Petrosino S, Schiano Moriello A, Cerrato S, Fusco M, Puigdemont A, De Petrocellis $L$, et al. The anti-inflammatory mediator palmitoylethanolamide enhances the levels of 2-arachidonoyl-glycerol and potentiates its actions at TRPV1 cation channels. Br J Pharmacol. 2016;173:1154-62.

21. Zygmunt PM, Ermund A, Movahed P, Andersson DA, Simonsen C, Jönsson BAG, et al. Monoacylglycerols activate TRPV1--a link between phospholipase C and TRPV1. PLoS ONE. 2013;8:e81618.

22. Musella A, Fresegna D, Rizzo FR, Gentile A, Bullitta S, De Vito F, et al. A novel crosstalk within the endocannabinoid system controls GABA transmission in the striatum. Sci Rep. 2017;7:7363.

23. Guida F, Luongo L, Boccella S, Giordano ME, Romano R, Bellini G, et al. Palmitoylethanolamide induces microglia changes associated with increased migration and phagocytic activity: involvement of the CB2 receptor. Sci Rep. 2017;7:375.

24. Lo Verme J, Fu J, Astarita G, La Rana G, Russo R, Calignano A, et al. The nuclear receptor peroxisome proliferator-activated receptor-alpha mediates the anti-inflammatory actions of palmitoylethanolamide. Mol Pharmacol. 2005;67:15-9.

25. Ambrosino P, Soldovieri MV, Russo C, Taglialatela M. Activation and desensitization of TRPV1 channels in sensory neurons by the PPARa agonist palmitoylethanolamide. Br J Pharmacol. 2013;168:1430-44.

26. Ambrosino P, Soldovieri MV, De Maria M, Russo C, Taglialatela M. Functional and biochemical interaction between PPARa receptors and TRPV1 channels: Potential role in PPARa agonists-mediated analgesia. Pharmacol Res. 2014; 87:113-22.

27. Facci L, Dal Toso R, Romanello S, Buriani A, Skaper SD, Leon A. Mast cells express a peripheral cannabinoid receptor with differential sensitivity to anandamide and palmitoylethanolamide. Proc Natl Acad Sci USA. 1995;92:3376-80.

28. De Filippis D, Russo A, De Stefano D, Cipriano M, Esposito D, Grassia G, et al. Palmitoylethanolamide inhibits $\mathrm{rMCP}-5$ expression by regulating MITF activation in rat chronic granulomatous inflammation. Eur J Pharmacol. 2014;725:64-9.

29. Mazzari S, Canella R, Petrelli L, Marcolongo G, Leon A. N-(2hydroxyethyl)hexadecanamide is orally active in reducing edema formation and inflammatory hyperalgesia by down-modulating mast cell activation. Eur J Pharmacol. 1996;300:227-36.

30. Costa B, Comelli F, Bettoni I, Colleoni M, Giagnoni G. The endogenous fatty acid amide, palmitoylethanolamide, has anti-allodynic and anti-hyperalgesic effects in a murine model of neuropathic pain: involvement of CB(1), TRPV1 and PPARgamma receptors and neurotrophic factors. Pain. 2008;139:541-50.

31. Bettoni I, Comelli F, Colombo A, Bonfanti P, Costa B. Non-neuronal cell modulation relieves neuropathic pain: efficacy of the endogenous lipid palmitoylethanolamide. CNS Neurol Disord Drug Targets. 2013;12:34-44.

32. luvone T, Affaitati G, De Filippis D, Lopopolo M, Grassia G, Lapenna D, et al. Ultramicronized palmitoylethanolamide reduces viscerovisceral hyperalgesia in a rat model of endometriosis plus ureteral calculosis: role of mast cells. Pain. 2016:157:80-91.

33. Gonsiorek W, Lunn C, Fan X, Narula S, Lundell D, Hipkin RW. Endocannabinoid 2-arachidonyl glycerol is a full agonist through human type 2 cannabinoid receptor: antagonism by anandamide. Mol Pharmacol. 2000;57:1045-50.

34. Petrosino S, Di Marzo V. FAAH and MAGL inhibitors: therapeutic opportunities from regulating endocannabinoid levels. Curr Opin Investig Drugs. 2010;11:51-62.

35. Bisogno T, Maurelli S, Melck D, De Petrocellis L, Di Marzo V. Biosynthesis, uptake, and degradation of anandamide and palmitoylethanolamide in leukocytes. J Biol Chem. 1997;272:3315-23.

36. Marsicano G, Wotjak CT, Azad SC, Bisogno T, Rammes G, Cascio MG, et al. The endogenous cannabinoid system controls extinction of aversive memories. Nature. 2002:418:530-4.

37. Grimaldi P, Orlando P, Di Siena S, Lolicato F, Petrosino S, Bisogno T, et al. The endocannabinoid system and pivotal role of the CB2 receptor in mouse spermatogenesis. Proc Natl Acad Sci USA. 2009;106:11131-6.

38. Ligresti A, Villano R, Allarà M, Ujváry I, Di Marzo V. Kavalactones and the endocannabinoid system: the plant-derived yangonin is a novel CB1 receptor ligand. Pharmacol Res. 2012;66:163-9.

39. Osman NA, Ligresti A, Klein CD, Allarà M, Rabbito A, Di Marzo V, et al. Discovery of novel Tetrahydrobenzo[b]thiophene and pyrrole based scaffolds as potent and selective CB2 receptor ligands: The structural elements controlling binding affinity, selectivity and functionality. Eur J Med Chem. 2016;122:619-34.
40. Bisogno T, Howell F, Williams G, Minassi A, Cascio MG, Ligresti A, et al. Cloning of the first sn1-DAG lipases points to the spatial and temporal regulation of endocannabinoid signaling in the brain. J Cell Biol. 2003;163:463-8.

41. Bisogno T. Assay of DAGLa/ $\beta$ Activity. Methods Mol Biol. 2016;1412:149-56.

42. Bisogno T, Ortar G, Petrosino S, Morera E, Palazzo E, Nalli M, et al. Development of a potent inhibitor of 2-arachidonoylglycerol hydrolysis with antinociceptive activity in vivo. Biochim Biophys Acta. 1791;2009:53-60.

43. Ortar G, Bisogno T, Ligresti A, Morera E, Nalli M, Di Marzo V. Tetrahydrolipstatin analogues as modulators of endocannabinoid 2 arachidonoylglycerol metabolism. J Med Chem. 2008;51:6970-9.

44. Malhotra R. Understanding migraine: Potential role of neurogenic inflammation. Ann Indian Acad Neurol. 2016;19:175-82.

45. Morita H, Saito H, Matsumoto K, Nakae S. Regulatory roles of mast cells in immune responses. Semin Immunopathol. 2016;38:623-9.

46. Ren. Interactions between the immune and nervous systems in pain. Nat Med. 2010;16:1267-76.

47. Ramachandran R. Neurogenic inflammation and its role in migraine. Semin Immunopathol. 2018;40:301-14.

48. Birder. Role of neurogenic inflammation in local communication in the visceral mucosa. - PubMed - NCBI [Internet]. [cited 2019 Oct 15]. Available from: https://www.ncbi.nlm.nih.gov/pubmed/29582112

49. Choi JE, Di Nardo A. Skin neurogenic inflammation. Semin Immunopathol. 2018:40:249-59.

50. Granberg M, Fowler CJ, Jacobsson SO. Effects of the cannabimimetic fatty acid derivatives 2-arachidonoylglycerol, anandamide, palmitoylethanolamide and methanandamide upon lgE-dependent antigen-induced betahexosaminidase, serotonin and TNF alpha release from rat RBL-2H3 basophilic leukaemic cells. Naunyn Schmiedebergs Arch Pharmacol. 2001; 364:66-73.

51. Conti S, Costa B, Colleoni M, Parolaro D, Giagnoni G. Antiinflammatory action of endocannabinoid palmitoylethanolamide and the synthetic cannabinoid nabilone in a model of acute inflammation in the rat. $\mathrm{Br} J$ Pharmacol. 2002;135:181-7.

52. Calignano A, La Rana G, Giuffrida A, Piomelli D. Control of pain initiation by endogenous cannabinoids. Nature. 1998;394:277-81.

53. Jaggar SI, Hasnie FS, Sellaturay S, Rice AS. The anti-hyperalgesic actions of the cannabinoid anandamide and the putative CB2 receptor agonist palmitoylethanolamide in visceral and somatic inflammatory pain. Pain. 1998;76:189-99.

54. Guindon J, Desroches J, Beaulieu P. The antinociceptive effects of intraplantar injections of 2-arachidonoyl glycerol are mediated by cannabinoid CB2 receptors. Br J Pharmacol. 2007;150:693-701.

55. Oka S, Ikeda S, Kishimoto S, Gokoh M, Yanagimoto S, Waku K, et al. 2arachidonoylglycerol, an endogenous cannabinoid receptor ligand, induces the migration of EoL-1 human eosinophilic leukemia cells and human peripheral blood eosinophils. J Leukoc Biol. 2004;76:1002-9.

56. Li H, Leeman SE, Slack BE, Hauser G, Saltsman WS, Krause JE, et al. A substance $P$ (neurokinin-1) receptor mutant carboxyl-terminally truncated to resemble a naturally occurring receptor isoform displays enhanced responsiveness and resistance to desensitization. Proc Natl Acad Sci USA. 1997;94:9475-80.

57. Vannacci A, Giannini L, Passani MB, Di Felice A, Pierpaoli S, Zagli G, et al. The endocannabinoid 2-arachidonylglycerol decreases the immunological activation of Guinea pig mast cells: involvement of nitric oxide and eicosanoids. J Pharmacol Exp Ther. 2004;311:256-64.

58. Cruz SL, Sánchez-Miranda E, Castillo-Arellano Jl, Cervantes-Villagrana RD, Ibarra-Sánchez A, González-Espinosa C. Anandamide inhibits FceRIdependent degranulation and cytokine synthesis in mast cells through CB2 and GPR55 receptor activation. Possible involvement of CB2-GPR55 heteromers. Int Immunopharmacol. 2018;64:298-307.

59. Cantarella G, Scollo M, Lempereur L, Saccani-Jotti G, Basile F, Bernardini R. Endocannabinoids inhibit release of nerve growth factor by inflammationactivated mast cells. Biochem Pharmacol. 2011;82:380-8.

60. Turcotte C, Chouinard F, Lefebvre JS, Flamand N. Regulation of inflammation by cannabinoids, the endocannabinoids 2-arachidonoylglycerol and arachidonoyl-ethanolamide, and their metabolites. J Leukoc Biol. 2015;97:1049-70.

\section{Publisher's Note}

Springer Nature remains neutral with regard to jurisdictional claims in published maps and institutional affiliations. 